\title{
Retinoic Acid Induces Blood-Brain Barrier Development
}

\author{
Mark R. Mizee, ${ }^{1}$ Desiree Wooldrik, ${ }^{1}$ Kim A. M. Lakeman, ${ }^{1}$ Bert van het Hof, ${ }^{1}$ Joost A. R. Drexhage, ${ }^{1}$ Dirk Geerts, ${ }^{4}$ \\ Marianna Bugiani, ${ }^{3}$ Eleonora Aronica, ${ }^{5}$ Reina E. Mebius, ${ }^{2}$ Alexandre Prat, ${ }^{6}$ Helga E. de Vries, ${ }^{1 \star}$ and Arie Reijerkerk ${ }^{7 \star}$ \\ ${ }^{1}$ Blood-Brain Barrier Research Group, Department of Molecular Cell Biology and Immunology, Neuroscience Campus Amsterdam, VU University Medical \\ Center, 1007 MB Amsterdam, The Netherlands, Departments of ${ }^{2}$ Molecular Biology and Immunology and ${ }^{3}$ Pathology, Free University Medical Center, 1007 \\ MB Amsterdam, The Netherlands, ${ }^{4}$ Department of Pediatric Oncology/Hematology, Sophia Children's Hospital, Erasmus University Medical Center, 3015 \\ CE Rotterdam, The Netherlands, ${ }^{5}$ Department of Neuropathology, Academic Medical Center, University of Amsterdam, 1012 WX Amsterdam, The \\ Netherlands, ${ }^{\circ}$ euroimmunology Research Laboratory, Hospital Complex of the University of Montréal, Notre Dame Hospital, Faculty of Medicine, \\ University of Montréal, Montréal, Quebec H2W 1T8, Canada, and ${ }^{7 B B B}$ Technologies B.V., 2333 CH Leiden, The Netherlands
}

The blood- brain barrier (BBB) is crucial in the maintenance of a controlled environment within the brain to safeguard optimal neuronal function. The endothelial cells (ECs) of the BBB possess specific properties that restrict the entry of cells and metabolites into the CNS. The specialized $\mathrm{BBB}$ endothelial phenotype is induced during neurovascular development by surrounding cells of the CNS. However, the molecular differentiation of the BBB endothelium remains poorly understood. Retinoic acid (RA) plays a crucial role in the brain during embryogenesis. Because radial glial cells supply the brain with RA during the developmental cascade and associate closely with the developing vasculature, we hypothesize that RA is important for the induction of BBB properties in brain ECs. Analysis of human postmortem fetal brain tissue shows that the enzyme mainly responsible for RA synthesis, retinaldehyde dehydrogenase, is expressed by radial glial cells. In addition, the most important receptor for RA-driven signaling in the CNS, RA-receptor $\beta$ ( $\operatorname{RAR} \beta$ ), is markedly expressed by the developing brain vasculature. Our findings have been further corroborated by in vitro experiments showing RA- and RAR $\beta$-dependent induction of different aspects of the brain EC barrier. Finally, pharmacologic inhibition of RAR activation during the differentiation of the murine $\mathrm{BBB}$ resulted in the leakage of a fluorescent tracer as well as serum proteins into the developing brain and reduced the expression levels of important $\mathrm{BBB}$ determinants. Together, our results point to an important role for RA in the induction of the BBB during human and mouse development.

\section{Introduction}

The vascular system of the CNS arises early in embryogenesis through the invasion of vascular plexus-forming angioblasts into the head region (Risau and Wolburg, 1990), followed by invasion of the CNS by vascular sprouts from the perineural vascular plexus, extending toward the ventricles (Greenberg and Jin, 2005). Peripheral vascular system development has been described in detail previously, and various signaling systems taking part in vasculogenesis, angiogenesis, and differentiation have been uncovered (Jain, 2003; Aird, 2007a,b). However, few reports exist on developmental CNS-specific cues for the induction of the specialized endothelial cell (EC) phenotype found at the blood-

Received March 15, 2012; revised Nov. 6, 2012; accepted Nov. 30, 2012.

Author contributions: M.R.M., H.E.d.V., and A.R. designed research; M.R.M., D.W., K.A.M.L., B.v.h.H., J.A.R.D., and A.R. performed research; D.G., M.B., E.A., R.E.M., and A.P. contributed unpublished reagents/analytic tools; M.R.M., M.B., H.E.d.V., and A.R. analyzed data; M.R.M. wrote the paper.

This work was supported by Dutch Foundation of MS Research Grants MS 07-615 (M.M.) and MS 08-642 and MS 09-689 (J.A.R.D.), Netherlands Organization of Scientific Research Grant 016.046.314 (K.A.M.L.), and Top Institute Pharma Grant T2-108 (A.R.). We thank Ruud Fontijn for providing us with qPCR primers and Serge van de Pavert for providing us with the RALDH1/2 antibody.

*H.E.d.V. and A.R. contributed equally to this work.

The authors declare no competing financial interests.

Correspondence should be addressed to Helga E. de Vries, Blood-Brain Barrier Research Group, Molecular Cell Biology and Immunology, Free University Medical Center, P.0. Box 7057, 1007 MB Amsterdam, The Netherlands. E-mail:he.devries@vumc.nl.

DOI:10.1523/JNEUROSCI.1338-12.2013

Copyright $\odot 2013$ the authors $\quad 0270-6474 / 13 / 331660-12 \$ 15.00 / 0$ brain barrier (BBB). This specialized EC phenotype includes the presence of interendothelial tight junctions, transporters, and efflux systems, together ensuring a CNS environment that favors proper neuronal function (Pachter et al., 2003; Abbott et al., 2010).

CNS cells surrounding the endothelial layer are thought to provide angiogenic ECs with the appropriate signals for $\mathrm{BBB}$ maturation (Stewart and Wiley, 1981), as well as signals required for maintenance of the mature BBB phenotype. During CNS development, radial glial cells provide structural and trophic cues (Chanas-Sacre et al., 2000) and differentiated astrocyte end-feet projections provide an almost complete enveloping of the brain microvasculature in adult vertebrates (Mathiisen et al., 2010). The search for CNS-specific signals that affect the BBB phenotype in brain ECs has implicated astrocytes and glial progenitors as inducers of a specific BBB-phenotype in brain EC (Abbott et al., 2006).

Radial glial cell-derived retinoic acid (RA) is crucial in providing the brain with the correct developmental pattern during neurogenesis (Környei et al., 2007), and RA has complex and pleiotropic functions during vertebrate development (for review, see Niederreither and Dollé, 2008). However, the role of RA as a developmental cue in the CNS vasculature has remained uninvestigated. RA is a retinol-derived lipophilic metabolite, synthesized by retinaldehyde dehydrogenases (RALDH1-RALDH3), and one of the first described powerful morphogens during de- 
velopment. RA signaling has been implicated in cell fate determination for a wide range of cells in developing mammals. RA signaling can only occur when retinol, bound to retinol binding protein (RBP), is taken up from the circulation. Uptake of RBPbound retinol occurs via the membrane-bound protein stimulated by retinoic acid gene 6 (STRA6) (Kawaguchi et al., 2007). Retinol is oxidized to retinaldehyde and further oxidized to retinaldehyde by RALDH enzymes, leading to freely diffusible RA, mainly acting in a paracrine manner. Target cells that express the nuclear RA receptors $\alpha, \beta$, or $\gamma(\operatorname{RAR} \alpha / \beta / \gamma)$ and the scaffolding retinoid X receptors $\alpha, \beta$, or, $\gamma(\mathrm{RXR} \alpha / \beta / \gamma)$ react to RA by the heterodimerization of RAR and RXR and subsequent transcription of genes with an upstream RA response element (RARE) (for review, see Duester, 2008).

In the current study, we set out to investigate the role of RA in $\mathrm{BBB}$ development. We provide insight in the spatiotemporal expression pattern of RALDH and RAR $\beta$ during human CNS development and show that RA mediates various aspects of brain ECs, both in vitro and in vivo.

\section{Materials and Methods}

Cell culture. The human brain EC line hCMEC/D3 (Weksler et al., 2005) was provided by Dr. P.-O. Couraud (Institut Cochin, Université Paris Descartes, Paris, France) and grown in endothelial cell basal medium-2 supplemented with human EGF, hydrocortisone, GA-1000, FBS, VEGF, human fibroblast growth factor (FGF)-B, R3-IGF-1, ascorbic acid, and $2.5 \%$ fetal calf serum (Lonza). To obtain astrocyte cultures, fetal tissue (cerebral hemispheres) was obtained at 17-23 weeks of gestation following Canadian Institute of Health Research-approved guidelines. Astrocyte isolation has been described previously (Wosik et al., 2007). Human fetal astrocytes were used between $\mathrm{P} 2$ and $\mathrm{P} 4$, and cultures were determined to be $>90 \%$ pure, as determined by glial fibrillary acidic protein (GFAP) immunostaining. Astrocyte-conditioned media (ACM) was harvested once a week from confluent flasks of human fetal astrocyte cultures.

Generation of recombinant hCMEC/D3 RAR $\beta$ knock-down cell lines. To establish knockdown of RAR $\beta$, we used a vector-based shRNA technique. shRNA was purchased from Sigma. Recombinant lentiviruses were produced by cotransfecting subconfluent human embryonic kidney 293T (HEK 293T) cells with the shRNA lentivirus expression plasmid and packaging plasmids (pMDLg/pRRE and pRSV-Rev) using calcium phosphate as a transfection reagent. HEK 293T cells were cultured in DMEM supplemented with $10 \%$ FCS and $1 \%$ penicillin/streptomycin, in a $37^{\circ} \mathrm{C}$ incubator with $5 \% \mathrm{CO}_{2}$. The RAR $\beta$-specific shRNA sequence was 5'-CTGGGTAAATACACCACGAAT-3'; nontargeting shRNA control vector was bought from Sigma. Infectious lentiviruses were collected $48 \mathrm{~h}$ after transfection. The supernatant was centrifuged to remove cell debris and stored at $-80^{\circ} \mathrm{C}$. hCMEC/D3 cells were transduced with the lentivirus containing shRNA, and, after $48 \mathrm{~h}$, cells stably expressing the shRNA containing construct were selected by puromycin-containing $(0.2 \times$ $10^{-7} \mathrm{~g} / \mathrm{ml}$ ) selection medium. After $48 \mathrm{~h}$ of selection, cells were maintained in normal medium.

Donor brain material. Immunohistochemistry was performed on tissue sections obtained from the brain collections of the Department of Neuropathology of the Academic Medical Center, University of Amsterdam (Amsterdam, The Netherlands). Parental consent was obtained for the use of brain tissue and for access to medical records for research purposes. The tissue was obtained from spontaneous or medically induced abortions, with appropriate parental written consent for brain autopsy. We also obtained normal-appearing control cortex at autopsy from two young cases ( 3 months and 7 months), without a history of seizures or other neurological diseases. All autopsies were performed within $12 \mathrm{~h}$ of death. Clinical data are presented in Table 1 . Ten percent buffered formalin-fixed, paraffin-embedded tissue blocks were sectioned at $6 \mu \mathrm{m}$ and mounted on organosilane-coated slides (Sigma) for immunohistochemistry. Frozen tissue blocks were sectioned at $6 \mu \mathrm{m}$ and mounted on Superfrost slides (Microm).
Table 1. Clinical information regarding the brain tissue used in this study

\begin{tabular}{llllll}
\hline Age & Sex & $\begin{array}{l}\text { Brain } \\
\text { weight }\end{array}$ & $\begin{array}{l}\text { Postmortem } \\
\text { delay (h) }\end{array}$ & $\begin{array}{l}\text { Fixation } \\
\text { time (weeks) }\end{array}$ & $\begin{array}{l}\text { Reason for termination } \\
\text { of pregnancy }\end{array}$ \\
\hline $10 \mathrm{gw}$ & $\mathrm{M}$ & $\mathrm{ND}$ & $\mathrm{ND}$ & 3 & Spontaneous abortus \\
$16 \mathrm{gw}$ & $\mathrm{F}$ & $15 \mathrm{~g}$ & 7 & 3 & Spontaneous abortus \\
$20 \mathrm{gw}$ & $\mathrm{F}$ & $23 \mathrm{~g}$ & 6 & Frozen & Heart defect \\
$22 \mathrm{gw}$ & $\mathrm{M}$ & $24 \mathrm{~g}$ & 6 & 3 & Spontaneous abortus \\
$29 \mathrm{gw}$ & $\mathrm{M}$ & $131 \mathrm{~g}$ & 8 & 3 & Heart defect \\
3 months & M & $572 \mathrm{~g}$ & 7 & 3 & \\
7 months & M & $962 \mathrm{~g}$ & 9 & 3 & \\
\hline
\end{tabular}

ND, Not determined or available; gw, gestational week; M, male; F, female.

Animal experiments. To achieve specific disturbance of RA signaling in the developing embryo, pregnant C57BL/6 mice (Charles River Laboratories) were treated with validated in vivo RAR antagonist BMS493 [4-[(1E)-2-[5,6Dihydro-5,5-dimethyl-8-(2-phenylethynyl)-2-naphthalenyl] ethenyl] benzoic acid] (Wendling et al., 2000) (5 mg/kg; Tocris Bioscience) or vehicle (DMSO) at 1:10 in nut oil. Hereto, mice were mated overnight, and the day of vaginal plug detection was marked as E0.5. Treatment was given by oral gavage twice daily, in 10-12 h intervals, and started at E10.5, during 6 consecutive days. At gestational day 16.5, the mice were killed, and the embryos were isolated from the uterus. To assess the permeability of the embryonic BBB, Cadaverine-Alexa Fluor 555 (5 mg/ml; Invitrogen) was injected intravenously $1 \mathrm{~h}$ before embryo isolation. Embryos were immediately fixed in $4 \%$ paraformaldehyde for $1 \mathrm{~h}$ to prevent diffusion of the tracer. For quantitative analysis of gene expression levels, embryonic brains were isolated and RNA isolation was performed using Trizol (Invitrogen) according to the protocol of the manufacturer. Downstream cDNA synthesis was performed as described below. For immunohistochemical analysis of protein expression, whole embryos were cryoprotected with $30 \%$ sucrose in PBS, embedded in $1.5 \%$ agarose, and snap frozen in liquid nitrogen. Whole embryos were cryosectioned as described above. Immunohistochemical analysis of tight junction protein zona occludens 1 (ZO-1), the endothelial marker platelet/endothelial cell adhesion molecule 1 (PECAM1), mouse IgG as an endogenous leakage marker, and neuronal nucleus marker (NeuN) are described under immunohistochemistry. The Animal Experiments Committee of the Free University Medical Center approved all of the experiments described in this study.

Immunohistochemistry. For single labeling of $\operatorname{RAR} \beta$ in human tissue sections, sections were deparaffinized and treated with $0.3 \% \mathrm{H}_{2} \mathrm{O}_{2}$ in methanol for $20 \mathrm{~min}$ to reduce endogenous peroxidase activity. Antigen retrieval was achieved by incubating the sections at $100^{\circ} \mathrm{C}$ in citrate buffer (10 mM in PBS, pH 6.0) for $10 \mathrm{~min}$. After washing with PBS, sections were treated with $0.1 \%$ saponin in PBS, washed, and subsequently incubated with primary antibody, polyclonal rabbit $\alpha \operatorname{RAR} \beta$ (Abcam), in PBS overnight at $4^{\circ} \mathrm{C}$. Slides were then washed and incubated with Envision + Dual link reagent (Dako) for $30 \mathrm{~min}$, followed by visualization with the peroxidase substrate diaminobenzidine (Dako). After a short rinse in tap water, sections were incubated with hematoxylin for $1 \mathrm{~min}$ and extensively washed with tap water for $10 \mathrm{~min}$. Finally, sections were dehydrated with ethanol, followed by xylene and mounted with Entellan (Merck).

Fluorescent immunohistochemistry for $\operatorname{RAR} \beta$ was performed using polyclonal rabbit $\alpha \operatorname{RAR} \beta$ (Abcam) and monoclonal mouse $\alpha$-PECAM1 (Dako). Tissue sections were stained as described above for single labeling; only peroxidase activity quenching was omitted, and all incubation steps were performed in the presence of $1 \%$ normal serum of the secondary antibody host (goat or donkey). Secondary antibodies used were goat $\alpha$-mouse IgG-Alexa Fluor-488, donkey $\alpha$-rabbit IgG-Alexa Fluor-555, and streptavidin-Alexa Fluor 488 (Invitrogen). After incubation with appropriate secondary antibodies, slides were washed and embedded in vinol mounting medium supplemented with $0.4 \% 4^{\prime}$,6-diamidino-2phenylindole (Invitrogen) to stain nuclei.

Immunohistochemistry on mouse embryonic sections was performed as described above with the following antibodies: rat $\alpha$-mouse IgG biotinylated (Vector Laboratories); rat $\alpha$-PECAM-1-Alexa Fluor-647 (Dako); rabbit $\alpha$-NeuN (Millipore); and rabbit $\alpha$-ZO-1 (Invitrogen). Fluorescence analysis was performed with a Leica DM6000 microscope 
equipped with Leica advanced fluorescence software. Quantification of immunoreactivity was performed using NIH ImageJ software by setting a threshold value of fluorescence above the background and calculating the area above threshold per micrograph. At least five different micrographs per group were used in the analysis.

For RALDH staining in the developing human cortex, cryosections were air dried and fixed in acetone for $10 \mathrm{~min}$. Sections were incubated as described above, overnight at $4^{\circ} \mathrm{C}$ with primary antibodies: mouse $\alpha$-GFAP-Cy3 (Sigma); rabbit $\alpha$ RALDH1/RALDH2 (van de Pavert et al., 2009) (Abcam); and mouse $\alpha$-vimentin, clone V9 (Millipore). After each incubation with a primary antibody, sections were washed and subsequently incubated with the appropriate secondary antibodies [donkey $\alpha$-rabbit IgG-Alexa Fluor-488 and goat $\alpha$-mouse IgG-Alexa Fluor 647 (Invitrogen)], washed, and embedded as described above. Confocal fluorescence analysis was performed with a Leica TCS SP2 confocal microscope equipped with Leica confocal software.

Immunocytochemistry. Fluorescent immunocytochemistry was performed as described for fluorescent immunohistochemistry, except for fixation method. Cultures of recombinant RAR $\beta$ or scrambled shRNA hCMEC/D3s were grown to confluence in eight-well $\mu$-slides (Ibidi), washed with ice-cold PBS, and fixed in $4 \%$ paraformaldehyde in PBS for $10 \mathrm{~min}$ at $4^{\circ} \mathrm{C}$. Fixed cells were shortly permeabilized with $0.1 \%$ Triton $\mathrm{X}-100$ in PBS, washed, and incubated overnight at $4^{\circ} \mathrm{C}$ with primary antibodies [mouse $\alpha$-VE-cadherin (BD Biosciences) and rabbit $\alpha$-ZO-1 (Invitrogen)], washed, and subsequently incubated with appropriate secondary antibodies: donkey $\alpha$-rabbit IgG-Alexa Fluor-488 and goat $\alpha$-mouse IgG-Alexa Fluor-647 (Invitrogen). Actin filaments were visualized with rhodamine phalloidin (Invitrogen).

Electric cell-substrate impedance sensing assay. ECISTM model 1600R (Applied BioPhysics) was used to measure the transendothelial electric resistance (TEER) of human hCMEC/D3 cell monolayers. A measure previously described to have a close inverse correlation with smallmolecule permeability (Santaguida et al., 2006). A total of 100,000 cells were seeded onto each well of an $8 \mathrm{~W} 10+$ electric cell-substrate impedance sensing (ECIS) array (Ibidi) coated with collagen, and impedance was measured at multiple frequencies in real time. Cells were either treated with a 1:1 mixture of ACM or control medium and EGM-2 containing $2.5 \%$ FCS, with or without $5 \mu \mathrm{M}$ RAR antagonists (Kagechika, 2002) LE135 (Tocris Bioscience) and LE540 (Wako Pure Chemicals) immediately after seeding. For ECIS measurements with an RAR agonist, cells were treated with indicated concentrations of RA (Sigma) or vehicle $(100 \% \mathrm{EtOH})$ directly after seeding. For specific RAR $\beta$ activation, the indicated concentrations of $\operatorname{RAR} \beta$ agonist and $\operatorname{RAR} \alpha / \gamma$ antagonist BMS453 (Tocris Bioscience) or vehicle (100\% DMSO) were added directly after seeding. BMS453 has confirmed activity in vitro (Germain et al., 2004) and in vivo (Matt et al., 2003). All ECIS measurements were furthermore subjected to a mathematical model to calculate the component of resistance attributed to cell-cell interactions, called barrier resistance $(\mathrm{Rb})$, and the component derived from average membrane capacitance of cells covering the electrode (membrane capacitance) (Giaever and Keese, 1991).

Real-time quantitative PCR. Gene expression analysis was performed on confluent monolayers of hCMEC/D3 cells in 24-well microplates (Corning) treated with either $5 \mu \mathrm{M}$ RA for various lengths of time or confluent monolayers of recombinant hCMEC/D3 cell lines expressing either RAR $\beta$ shRNA or scrambled shRNA. mRNA was isolated using an mRNA capture kit (Roche) according to the instructions of the manufacturer. cDNA was synthesized with the Reverse Transcription System kit (Promega) following the guidelines of the manufacturer, and RT-PCR was performed as described previously (García-Vallejo et al., 2004). Primer sequences used are as follows, describing the forward and reverse sequence, respectively: human: $\mathrm{CDH} 5$, TGACGTGAACGACAACTGGC and GACGCATTGAACAACCGATG; ABCB1, GTCCCAGGAGCCCATCCT and CCCGGCTGTTGTCTCCAT A; OCLN, CCCGTTTGGATAAAGAATTGG and TCAAACAACTTGGC ATGAGC; VEGF-A, CATCTTCAAGCCATCCTGTGTG and GCATGGTG ATGTTGGACTCCT; TJP-1, CCCGAAGGAGTTGAGCAGGAAATC and CCACAGGCTTCAGGAACTTGAGG;SLC2A1,GCAGCAGCCTGTGTAT GCC and AAGGCCGTCTTGACGATACC; RARB, GCAGAGCGTGTAAT TACCTTGAAandGTGAGATGCTAGGACTGTGCTCT;RARA,AGATTA
CTGACCTGCGAAGC and CCCTCTGAGTTCTCCAACATTTC; RARG, CCTTGTCTTTGCCTTTGCTG and CAGGTCCATGCGGTCTC; and GAPDH, CCATGTTCGTCATGGGTGTG and GGTGCTAAGCAGTTGG TGGTG; murine: $C d h 5$, CAGCAACTTCACCCTCATAAAC and TCCCGA TTAAACTGCCCATAC; Tjp-1, AGCGAATGTCTAAACCTGGG and TC CAACTTGAGCATACACAGG; A $c c g 2$, GTTACCACTGTGAGCCCTA and TCTGTCTTGTTTGCTTCATGG; Rarb, GCCTGCAGAAGTGCTTTG AAGT and GCTCTCTGTGCATTCCTGCTTT; Gfap, CAGACTTTCTCC AACandCTCCTGCTTCGAGTC; Rbfox3,ATCCTTACCATCACACCATC G and GGAGACGGTGGAAGGTTTC; Pdgfrb, AGTGATGTCTGGTCT and TGGCATTGTAGAACT; and Pecam1, TGGTTGTCATTGGAGTGG TC and TTCTCGCTGTTGGAGTTCAG. Expression levels of transcripts obtained with real-time PCR were normalized to GAPDH expression levels. All conditions investigated were measured as quadruplicates.

Western blotting. Protein expression levels of VE-cadherin and ZO-1 were investigated in confluent monolayers of hCMEC/D3 cells grown in six-well microplates (Corning), treated with indicated concentrations of RA or vehicle for $48 \mathrm{~h}$. Cells were washed with ice-cold PBS and lysed in cell lysis buffer (Cell Signaling Technology) containing complete protease inhibitor cocktail (Roche) at $4^{\circ} \mathrm{C}$ for $30 \mathrm{~min}$. Cell lysates were then taken up in SDS sample buffer (100 mu Tris-HCl, pH 6.8), 4\% SDS, $20 \%$ glycerol, and $5 \% \beta$-mercaptoethanol) and heated to $95^{\circ} \mathrm{C}$ for $5 \mathrm{~min}$. Lysates were then resolved on SDS-PAGE in triplicate, blotted, and incubated overnight with the primary antibodies mouse $\alpha$-VEcadherin (Santa Cruz Biotechnology), rabbit $\alpha$-ZO-1 (Invitrogen), and goat $\alpha$-Actin (Santa Cruz Biotechnology) in Odyssey blocking buffer (LI-COR) diluted 1:1 in PBS, after initial blocking with blocking buffer for $1 \mathrm{~h}$ at room temperature. Primary antibodies were detected and quantified by incubation with appropriate IRDye secondary antibodies (at room temperature for $1 \mathrm{~h}$ in blocking buffer) and the Odyssey infrared imaging system (LI-COR). Actin quantification was used to correct for total protein loading.

Promoter-reporter constructs. The lentiviral vector pRRL-cPPTCMV-X2-PRE-SIN (kindly provided by Dr. J. Seppen, Department of Experimental Hepatology, Academic Medical Center, Amsterdam, The Netherlands) was modified for use as a carrier of promoter-reporter cassettes as described previously (Fontijn et al., 2008). The reporter plasmid pGL-RARE-luciferase containing trimerized RAREs in front of the firefly luciferase gene was described previously (Weston et al., 2002). RARE promoter-reporter cassettes were transferred from pGLRAREluciferase as NotI-SalI fragments containing successively a synthetic pA/ transcriptional pause site, a RARE promoter fragment, the firefly luciferase reporter gene, and the simian virus 40 (late) polyadenylation signal. The resulting lentiviral RARE promoter-firefly luciferase reporter vector was then packaged, in the presence of a small amount $(5 \% \mathrm{w} / \mathrm{w})$ of the herpes simplex virus thymidine kinase Renilla luciferase lentiviral vector (Fontijn et al. 2008), using HEK 293T cells. Virus-containing supernatants were used for transductions, and luciferase activities were measured after at least $2 \mathrm{~d}$, after $24 \mathrm{~h}$ of ACM exposure as described for the ECIS experiments using the dual luciferase system (Promega). Renilla luciferase levels were used to normalize firefly luciferase activity.

Statistical analyses. Data analysis was performed using GraphPad Prism software (version 5.01; GraphPad Software). Results are shown as mean \pm SEM, and statistical analysis was performed with either unpaired, two-tailed Student's $t$ test or with one- or two-way ANOVA and subsequent Bonferroni's post hoc test correction. The applied test for each calculated value is described in the figure legends.

\section{Results}

Human fetal astrocytes increase brain endothelial barrier formation by a RA signaling pathway

To gain insight into RA production in the CNS, we first analyzed the expression of the RA synthesizing enzyme RALDH1/2 in developing and neonatal human brain material. Immunohistochemistry analysis of RALDH1/2 showed a distinct radial expression profile during human cortical development (Fig. 1A). Colocalization studies with antibodies against the radial glial cell markers vimentin and GFAP revealed ample expression of 
A
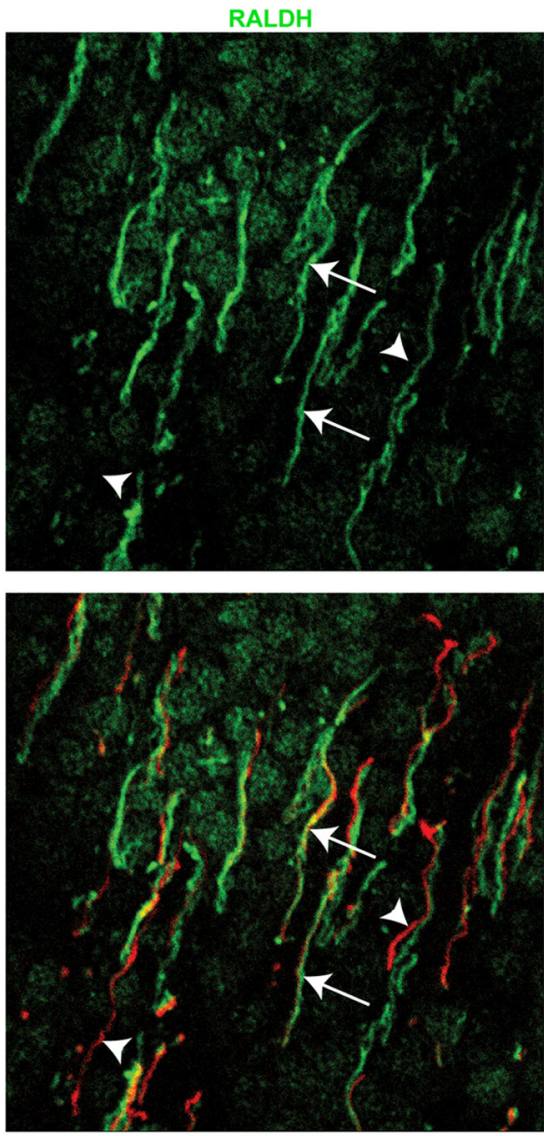

RALDH/GFAP

B

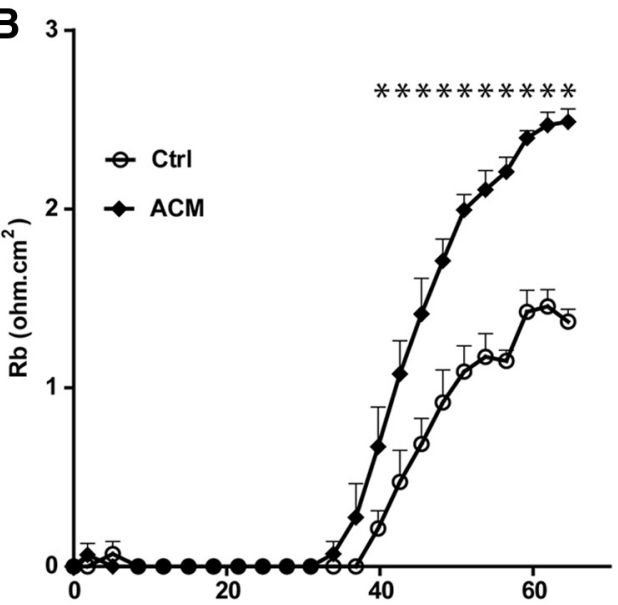

GFAP
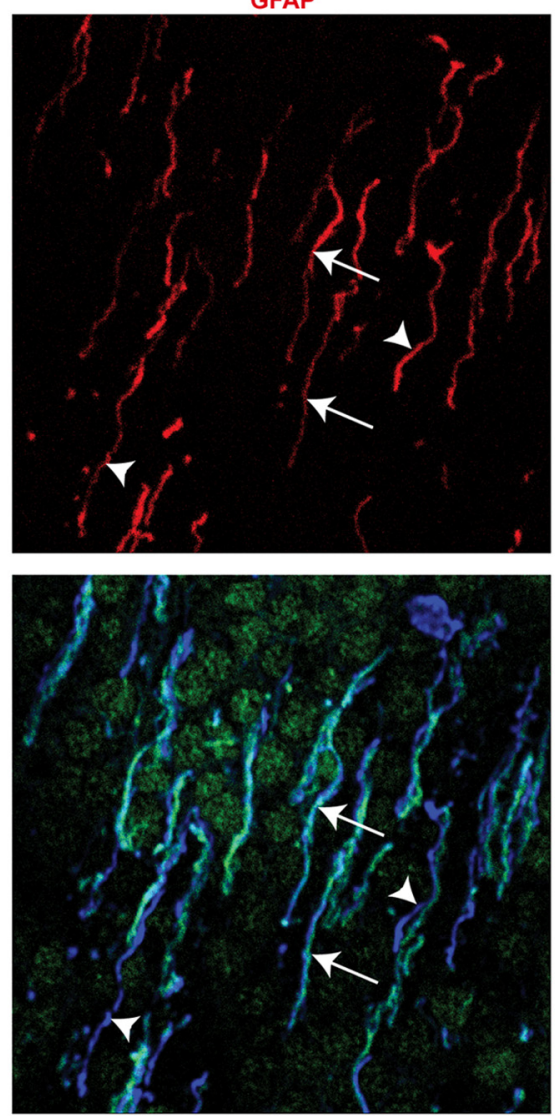

RALDH/Vimentin

C

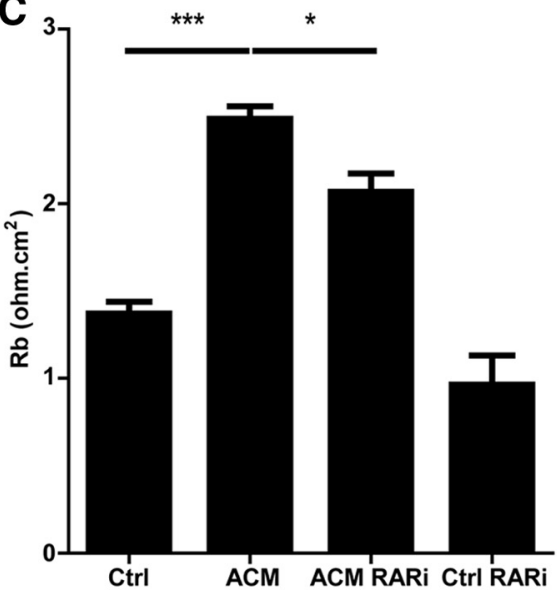

Vimentin
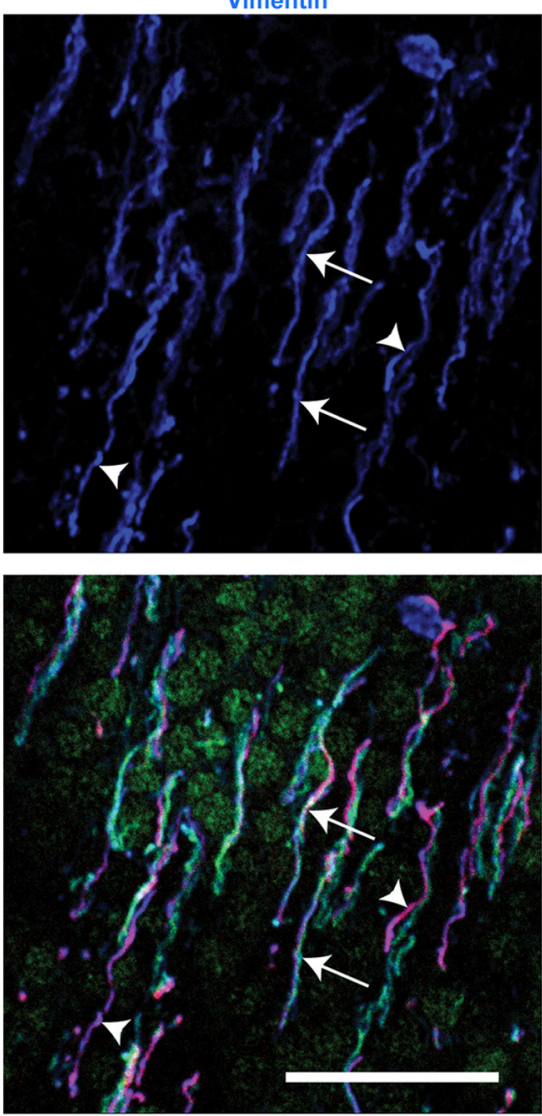

Merge all

D

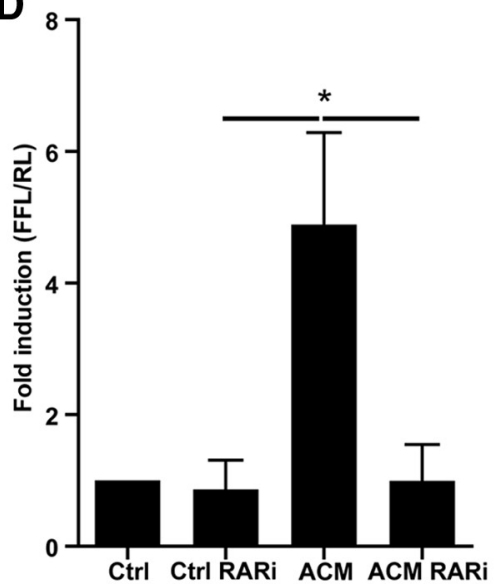

Figure 1. Fetal astrocyte-derived RA increases the resistance of brain ECS. A, Immunohistochemical analysis in human brain showing the expression of RALDH (green), GFAP (red), and vimentin (blue) in fetal cortex at 20 weeks of gestation. Note that RALDH-positive structures mostly overlap with both GFAP and vimentin-positive cells (arrows). RALDH-positive structures negative for GFAP and vimentin were also detected (arrowheads). Scale bar, $50 \mu \mathrm{m} . \boldsymbol{B}, \mathrm{Rb}$ (Ohms per square centimeters) of hCMEC/D3 cells during stimulation with fetal astrocyte factors is increased over time compared with control medium. * reflect significant differences compared with control (2-way ANOVA). C, Quantification of maximal Rb reached during an experiment similar to $B$. The addition of RAR antagonists LE135 and LE540 (ACM RARi) decreases the barrier-enhancing effect of fetal astrocyte factors on hCMEC/D3s (ACM), whereas vehicle-treated cells (Ctrl RARi) show no significant decrease compared with the control condition (Ctrl) (1-way ANOVA). D, Quantification of RARE-luciferase activity in hCMEC/D3 cells after ACM stimulation compared with control medium (Ctrl). The increase in luciferase activity is blocked by addition of RAR antagonists LE135 and LE540 (ACM + RARi). Addition of RAR antagonists to control medium-treated cells (Ctrl RARi) has no effect on luciferase activity (1-way ANOVA). ${ }^{*} p<0.05 ;{ }^{* * *} p<0.001 ; n=4$ for all experimental conditions.

RALDH1/2 in radial glial cells during development. The presence of RALDH1/2 was not fully restricted to radial glial cells, suggestive of RA-synthesizing capacity for other cell types, such as neuronal precursors as well. To investigate the role of RA in the communication between fetal astrocytes and ECs of the BBB, we next established the effect of soluble fetal astrocyte factors on one of the hallmark characteristics of brain ECs, the formation of a tight barrier. For this, hCMEC/D3s were seeded at confluence, and TEER was measured over time. Continuous exposure of the endothelial monolayers to ACM significantly increased TEER levels compared with unconditioned medium (maximum of $258.0 \pm 63.7 \Omega ; n=4$ ). To investigate the different components contributing to TEER, Rb was calculated and plotted over time. Fetal astrocyte factors also induced a significant increase in $\mathrm{Rb}$ 
levels (maximum of $1.1 \pm 0.1 \Omega / \mathrm{cm}^{2} ; n=4$; Fig. $1 B$ ), whereas cell spreading and proliferation were unaffected (data not shown). This indicates that the barrier-enhancing effect of fetal astrocyte factors is mainly attributable to increased function of interendothelial junctions.

To test our hypothesis that RA signaling is required for the increase in endothelial barrier function induced by ACM, we made use of the RAR antagonist combination LE135 and LE540 to block RAR activation by RA. The previously observed increase of $\mathrm{Rb}$ formation by fetal astrocyte factors was partially blocked by inhibition of the RARs in hCMEC/D3s (maximum of $37.34 \pm$ $11.39 \%$ of increase; $n=4$; Fig. $1 C$ ). Finally, to investigate whether exposure to fetal astrocyte factors leads to the activation of an RA signaling pathway in hCMEC/D3s, a RARE-luciferase reporter construct was introduced into hCMEC/D3s before exposure. Exposure to ACM resulted in an almost fivefold increase in endothelial luciferase expression compared with control medium (Fig. $1 D)$. Notably, the ACM-induced increase in RARE-driven luciferase expression could be completely abolished by LE135/ LE540, showing that exposure to fetal ACM results in RARdependent RARE activation. Together, these results implicate RA signaling in the barrier-enhancing effect of fetal astrocyte factors on human brain ECs.

\section{RA signaling in human brain ECs leads to increased barrier formation and the expression of $\mathrm{BBB}$-specific genes}

To gain more insight into the RA-mediated induction of $\mathrm{BBB}$ properties in hCMEC/D3s, we used various concentrations of all-trans RA (RA) in our in vitro ECIS assay. Continuous RA treatment resulted in a concentration-dependent increase of $\mathrm{Rb}$ of a confluent monolayer hCMEC/D3s over time when compared with vehicle-treated cells (Fig. 2A, maximal resistance (arrow): $0.1 \mu \mathrm{M}, 9.8 \pm 1.9 \%$ increase; $1 \mu \mathrm{M}, 15.4 \pm 2.4 \%$ increase; 5 $\mu \mathrm{M}, 21.0 \pm 2.5 \%$ increase; $n=4)$. Continuous treatment with 5 $\mu \mathrm{M}$ RA resulted in a $21 \%$ increase of the maximal $\mathrm{Rb}$ value reached in vehicle-treated cells, whereas cell spreading and proliferation were unaffected (data not shown).

The $\mathrm{BBB}$ phenotype is dependent on the expression of various proteins that contribute to tight junctions (VE-cadherin and occludin), transendothelial transport of nutrients [glucose transporter 1 (Glut-1)], and efflux pumps [P-glycoprotein (P-gp)]. To assess whether RA signaling in $\mathrm{hCMEC} / \mathrm{D} 3 \mathrm{~s}$ regulates $\mathrm{BBB}-$ related gene expression, we investigated the gene expression levels of P-gp, VE-cadherin, occludin, and Glut-1, after RA treatment. Treatment of confluent cultures of hCMEC/D3s with $5 \mu \mathrm{M}$ RA for $48 \mathrm{~h}$ leads to increased gene expression levels of P-gp (318.6 $\pm 1.5 \%$ of control), VE-cadherin (172.2 $\pm 24.9 \%$ of control), and occludin (162.3 $\pm 6.5 \%$ of control) (Fig. $2 B)$. Glut-1 gene expression was only significantly increased after $6 \mathrm{~h}$ of RA stimulation ( $131.7 \pm 6.7 \%$ of control). Conversely, the gene expression level of the permeability-related factor VEGF-A is decreased during RA stimulation. As expected, RA treatment increased the expression of the known RA target gene RAR $\beta$ $(283.2 \pm 35.7 \%$ of control).

To determine protein expression of the RA-induced barrier genes, we performed Western blot analysis of two important determinants of BBB integrity, ZO-1 and VE-cadherin. ZO-1 and VE-cadherin protein expression was significantly and concentration dependently increased after treatment with either 1 or $5 \mu \mathrm{M}$ RA for $48 \mathrm{~h}$ compared with vehicle controls (ZO-1: $1 \mu \mathrm{M}$ RA, $218.2 \pm 49.6 \%$ of control; $5 \mu \mathrm{M}$ RA, $302.4 \pm 42.4 \%$ of control; VE-cadherin: $1 \mu \mathrm{M}$ RA, $114.8 \pm 2.5 \%$ of control; $5 \mu \mathrm{M}$ RA, $127.7 \pm 9.7 \%$ of control; Fig. $2 C$ ). The increase in protein expres- sion for both VE-cadherin and ZO-1 was found to be functionally localized to cell-cell junctions by immunocytochemical analysis (Fig. 2D).

Together, these data show that RA is capable of inducing a tight barrier phenotype in human brain ECs by influencing gene and protein expression of molecules that are important for barrier function.

\section{$\operatorname{RAR} \beta$ in human brain ECs is critical for barrier integrity}

Because $\operatorname{RAR} \beta$ is the most important receptor in CNS-specific RA signaling (Mey, 2006; Wong et al., 2006), we used BMS453 as a specific $\operatorname{RAR} \beta$ agonist and $\operatorname{RAR} \alpha / \gamma$ antagonist in our in vitro systems. In hCMEC/D3 cells, RAR $\beta$ is the most abundantly expressed RAR subtype (Fig. 3A). Treatment of hCMEC/D3 cells with BMS453 resulted in a concentration-dependent increase in $\mathrm{Rb}$ over time compared with the vehicle control (Fig. 3B, maximal resistance (arrow): $0.1 \mu \mathrm{M}$ BMS453, $11.3 \pm 2.4 \%$ increase; 1 $\mu \mathrm{M}$ BMS453, $16.7 \pm 2.3 \%$ increase; $5 \mu \mathrm{M}$ BMS453, $27.2 \pm 1.7 \%$ increase; $n=4)$. Moreover, RAR $\beta$ activation resulted in a relative increase of the maximal Rb highly similar to comparable concentrations of RA (Fig. 2B). Cell spreading and proliferation were similar between all conditions (data not shown). To further enhance our understanding of the function of RAR $\beta$ at the $B B B$, we specifically knocked down its expression in hCMEC/D3s by using a lentivirus encoding RAR $\beta$-specific or a nontargeting shRNA. Both recombinant cell lines were able to form a confluent monolayer under standard culture conditions. However, when compared with control cells, hCMEC/D3s with reduced RAR $\beta$ gene expression (33.8 $\pm 11.3 \%$ of control; Fig. $3 E$ ) failed to form normal Rb. Whereas RA still enhanced the barrier in control cells expressing nontargeting shRNA, RA stimulation was not able to restore the impaired $\mathrm{Rb}$ formation in $\mathrm{RAR} \beta$-deficient cells (Fig. $3 C)$. Together, the results revealed a role for constitutive RAR $\beta$ activity in hCMEC/D3 barrier formation under normal culture conditions. To investigate the molecular alterations underlying the observed changes on $\mathrm{Rb}$ formation, we performed fluorescent immunocytochemistry analysis of two important barrier determining molecules, VE-cadherin and ZO-1, on confluent monolayers of both cell lines. Although actin distribution and expression was comparable between cell lines, a striking decrease of both VE-cadherin and ZO-1 immunostaining was observed in the cells with reduced $\operatorname{RAR} \beta$ expression compared with the control cells (Fig. 3D). Furthermore, the overlapping pattern of VEcadherin and ZO-1 is lost in the areas in which junctional expression of VE-cadherin or ZO-1 is preserved. The loss of a BBB phenotype after RAR $\beta$ knockdown was also apparent from gene expression analysis of barrier-related genes (Fig. 3E). RAR $\beta$ knockdown resulted in decreased gene expression levels of VEcadherin ( $25.4 \pm 8.1 \%$ of control), Glut-1 (42.2 $\pm 4.2 \%$ of control), and ZO-1 (43.4 $\pm 13.7 \%$ of control). However, P-gp mRNA levels remained unaltered by RAR $\beta$ knockdown, suggesting a pathway other than $\operatorname{RAR} \beta$ activation in the RA-induced upregulation of P-gp gene expression. Finally, permeabilityrelated factor VEGF-A was highly increased during RAR $\beta$ knockdown $(211.3 \pm 14.4 \%$ of control). These experiments show that part of the barrier function of hCMEC/D3s is dependent on the presence of $\operatorname{RAR} \beta$.

\section{$\operatorname{RAR} \boldsymbol{\beta}$ expression is located in microvascular structures during embryogenesis}

Together, our experiments not only point out that $\operatorname{RAR} \beta$ is involved in RA-induced barrier function but also suggest a role for $\operatorname{RAR} \beta$ in the development of the BBB. To address this hypothesis, 

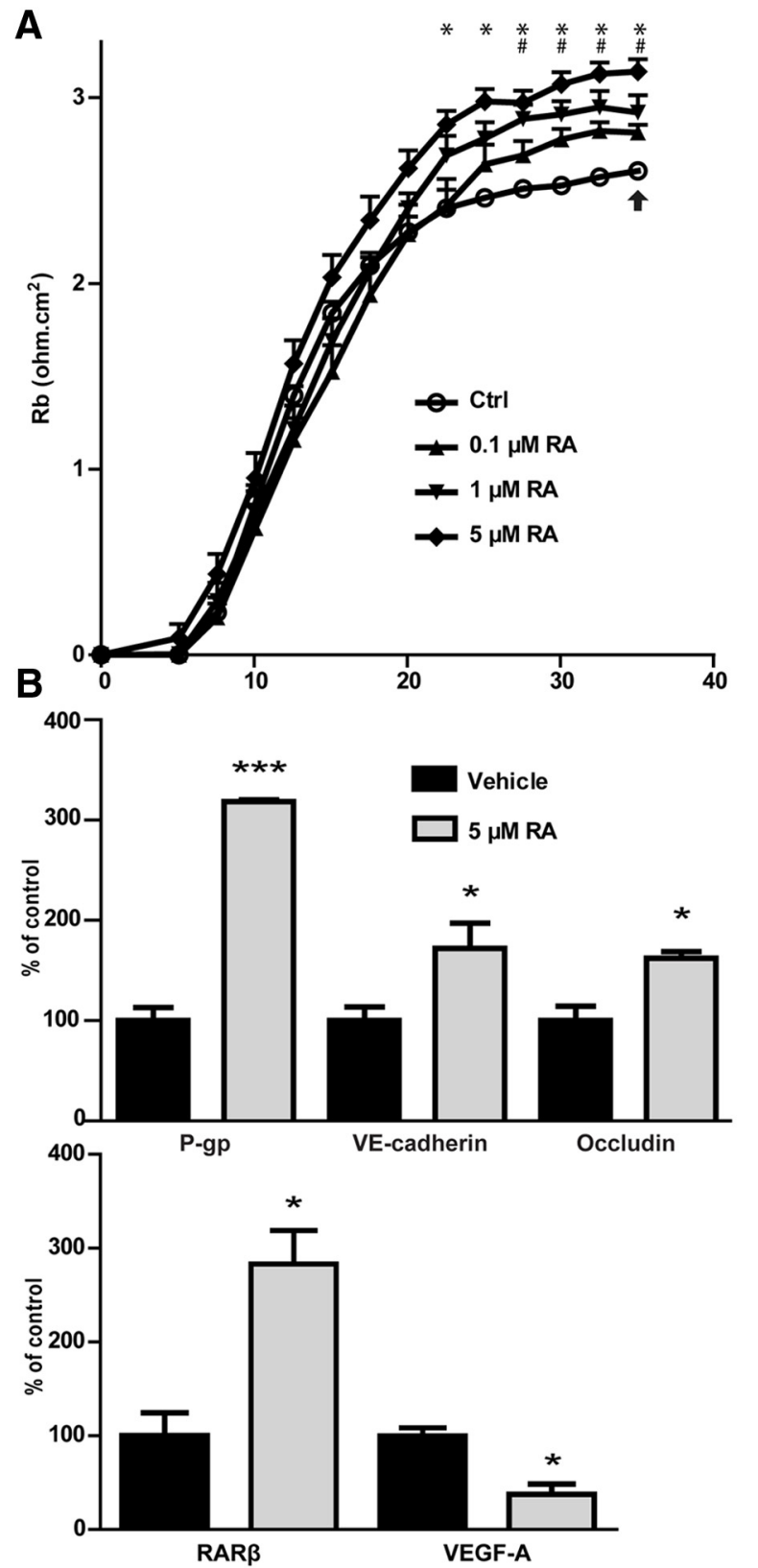

C
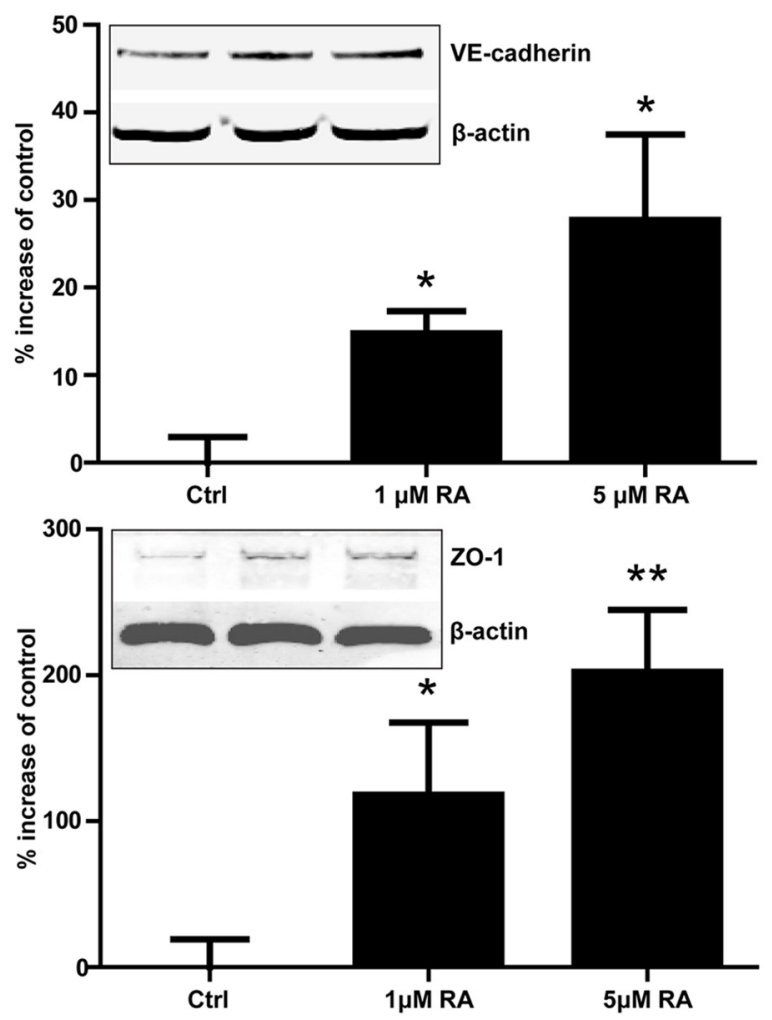

D
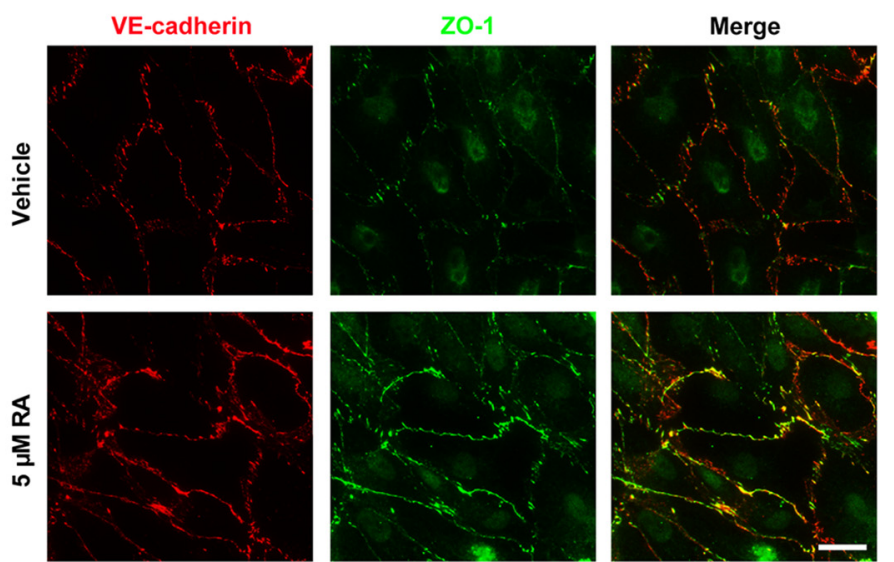

Figure 2. RA increases barrier formation of brain ECs by inducing barrier-related gene expression. $A$, Rb formation over time of hCMEC/D3s increases during RA treatment in a concentration-dependent manner compared with vehicle-treated cells (Ctrl). Arrow indicates the maximal Rb value. * and \# reflect significant differences compared with control for 5 and $1 \mu m$ RA, respectively ( 2 -way ANOVA). $\boldsymbol{B}$, Expression levels of barrier-related genes are increased after RA $(48 \mathrm{~h}, 5 \mu \mathrm{m})$ treatment. Gene expression level of permeability-related VEGF-A is decreased, whereas gene expression level of RA-target gene RAR $\beta$ is increased, after RA (48 h, $5 \mu \mathrm{m}$ ) exposure (2-tailed Student's $t$ test). C, Quantification of VE-cadherin and Z0-1 protein expression as measured by Western blot, corrected for actin. Both Z0-1 and VE-cadherin protein levels in whole-cell lysates of hCMEC/D3s stimulated with RA (48 h, $5 \mu \mathrm{m}$ ) increase significantly in a concentration-dependent manner (1-way ANOVA). Insets show representative images of the specific bands measured, both experiments performed in triplicate. $\boldsymbol{D}$, Immunocytochemical analysis of VE-cadherin (red) and Z0-1 (green) expression of hCMECD3 cells stimulated as described in $\boldsymbol{C}$. Note that the RA-induced increase in expression of both proteins localizes to the cell-cell junctions. Scale bar, $20 \mu \mathrm{m} .{ }^{*} p<0.05$; $^{* *} p<0.01$; ${ }^{* * *} p<0.001$.

we analyzed $\operatorname{RAR} \beta$ expression in human fetal brain tissue, in various stages of development, by immunohistochemistry (Fig. $4 A$ ). As early as 10 weeks of gestation, $\mathrm{RAR} \beta$ expression is evident in structures with vascular morphology but can also be found in multiple other cell types, and many structures with vascular morphology are devoid of RAR $\beta$ expression. Vascular RAR $\beta$ expression becomes more pronounced at the later developmental stages of 22 and 29 weeks of gestation when most vascular structures are $\mathrm{RAR} \beta$ positive. Moreover, its expression coincided with the BBB markers ZO-1 and occludin. Glut-1 immunoreactivity precedes the presence of $\operatorname{RAR} \beta$, with pronounced vascular immunoreac- tivity from 10 weeks of gestation. Costaining with an antibody against PECAM1 confirms the vascular nature of RAR $\beta$-positive cells (Fig. 4B). Assessment of RAR $\beta$ expression in 3 (data not shown) and 7 (Fig. 4A) months postnatal human cortical tissue revealed no abundant vascular expression pattern. Whereas the expression pattern of ZO-1, occludin, and Glut-1 remain present in postnatal tissues, $\operatorname{RAR} \beta$ expression is mainly restricted to neurons. A similar developmental pattern can be observed by analyzing $\operatorname{RAR} \beta$ gene expression in whole mice brain lysates from different developmental stages, corrected for vascular content (PECAM1). Relative RAR $\beta$ expression shows a decline as the 
A

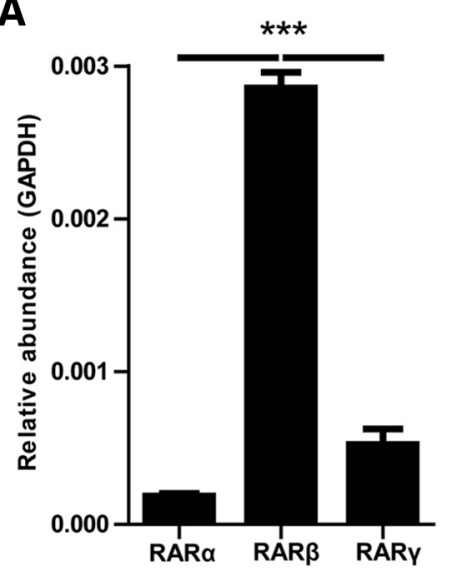

D
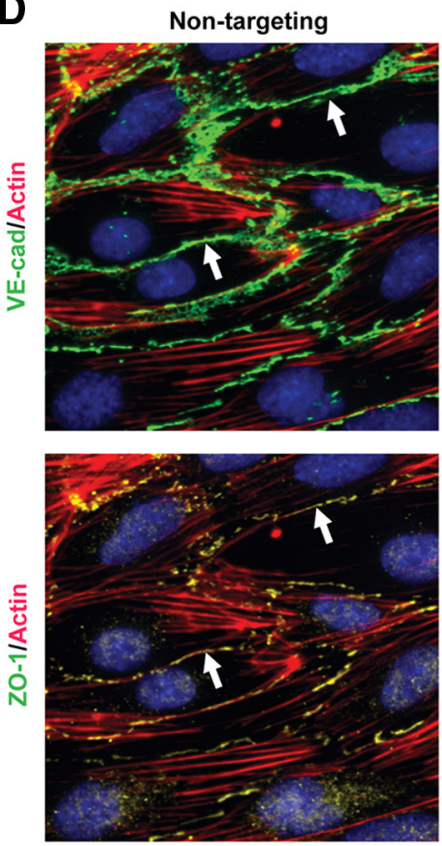

B

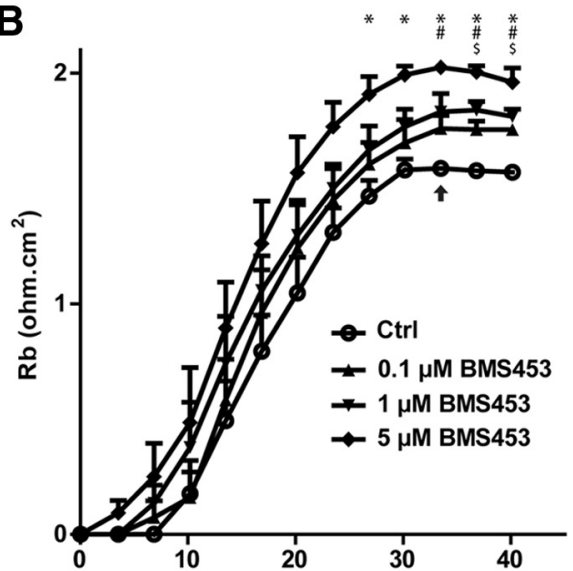

RAR $\beta$ KD
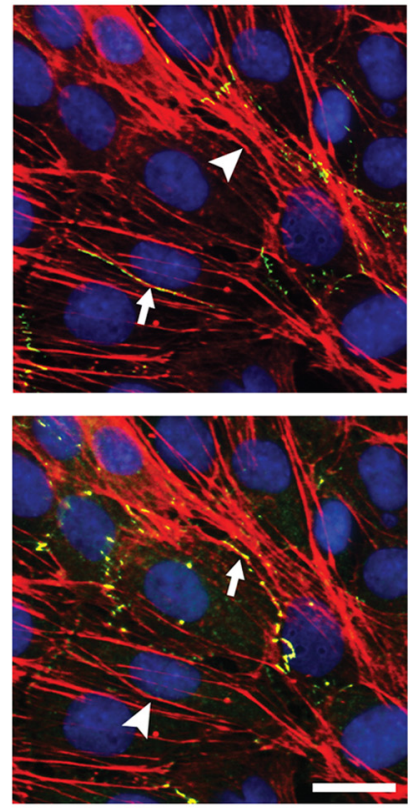

C

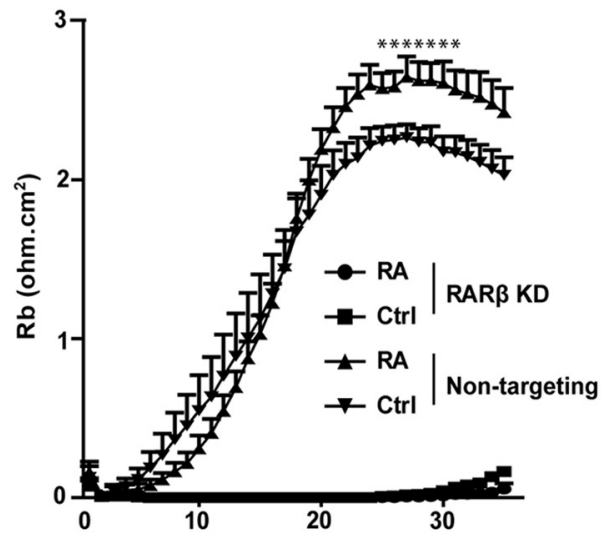

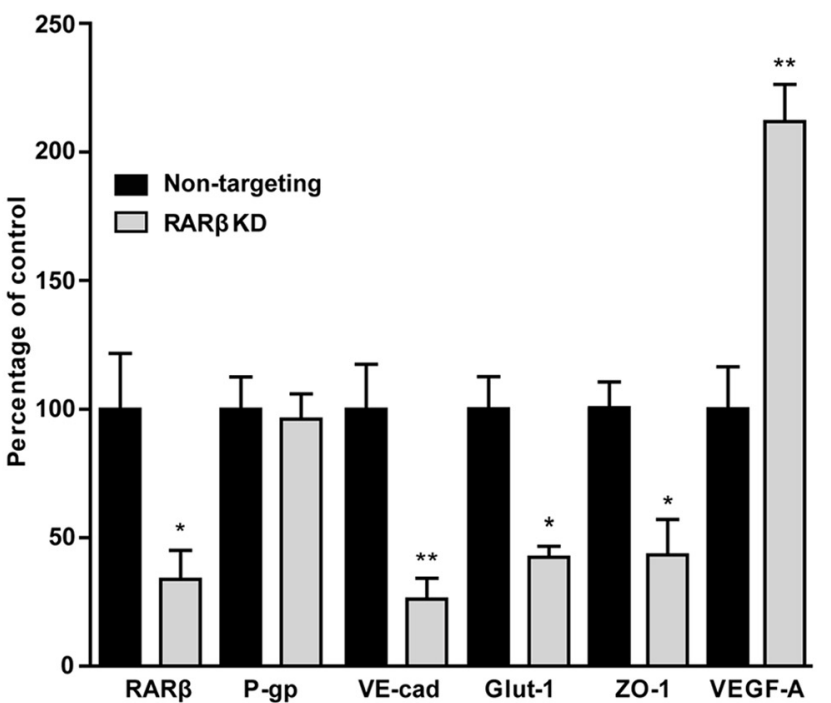

Figure 3. RAR $\beta$ is the dominant RAR involved in barrier formation. $A$, Relative abundance of RAR subtypetranscripts in hCMEC/D3 cells compared with GAPDH (1-way ANOVA). B, Rb formation of hCMEC/D3s over time rises with increasing concentrations of RAR $\beta$ agonist BMS453. Arrow indicates the maximal Rb value reached. ${ }^{*}$, $\#$, and $\$$ reflect significant differences compared with control for 5,1 , and $0.1 \mu \mathrm{M}$, respectively (2-way ANOVA). C, Rb values of hCMEC/D3 cells that lack RAR $\beta$ by lentiviral shRNA knockdown fail to generate Rb over time. Rb levels of hCMEC/D3 cells transduced with nontargeting shRNA are increased by stimulation with $5 \mu \mathrm{MRA} .{ }^{*}$ reflect significant differences of nontargeting + RA compared with control (2-way ANOVA).D, Immunohistochemical analysis showing anti-VE-cadherin or ZO-1 (green) and actin fibers (red). hCMEC/D3 cells transduced with nontargeting shRNA (nontargeting) show junctional and overlapping localization of VE-cadherin and Z0-1 (arrows), as well as normal actin distribution. hCMEC/D3 cells transduced with RAR $\beta$ shRNA (RAR $\beta$ KD) show highly decreased VE-cadherin and Z0-1 staining. Junctional localization of VE-cadherin and Z0-1 (arrows) and actin distribution is preserved, although little to no overlap between VE-cadherin and Z0-1 is observed (arrowheads). Scale bar, $20 \mu \mathrm{m}$. $E$, Barrier-related gene expression levels, as well as RAR $\beta$ gene expression level, are decreased in RAR $\beta$ shRNA-expressing hCMEC/D3 cells compared with nontargeting shRNA. However, P-gp expression level remains unaffected by the knockdown of RAR $\beta$ gene expression, whereas the gene expression level of VEGF-A is highly increased (2-tailed Student's $t$ test). ${ }^{*} p<0.05 ;{ }^{* *} p<0.01 ;{ }^{* * *} p<0.001 ; n=4$ for all experimental conditions.

brain develops and is significantly lower in adult brain compared with all earlier stages (Fig. 4C). The presence of RAR $\beta$ in vascular structures during human brain development and the simultaneous appearance of BBB markers $\mathrm{ZO}-1$ and occludin suggest a role for RAR $\beta$ in the maturation process of brain ECs during a specific time window early in development, resulting in the loss of vascular $\operatorname{RAR} \beta$ expression shortly before or after birth.

RA signaling is necessary for $\mathrm{BBB}$ formation in the developing mouse brain

To investigate the relevance of RA signaling in BBB development in vivo, we treated pregnant mice with the RAR antagonist BMS493, from gestational age 10.5 to 16.5 . By starting at $10.5 \mathrm{~d}$ of gestation, we can exclude disturbance of normal brain develop- ment until the nervous vascular plexus starts to invade the CNS parenchyma (Walls et al., 2008). BMS493 treatment resulted in a distinct embryonic appearance, including smaller size, incomplete eye development and pigmentation, and an edematous formation in the neck, corresponding with that found in RAdeficient animals (Quadro et al., 2005). The permeability of the embryonic cerebral vessels (PECAM1 positive) was assessed by immunohistochemical detection of endogenous IgG and the accumulation of circulating Cadaverine-Alexa Fluor-555. In the CNS of embryos from vehicle-treated pregnant mice, IgG immunoreactivity was exclusively located within the vasculature, whereas Cadaverine-Alexa Fluor-555 was not detected. However, the CNS of embryos from BMS493-treated pregnant mice displayed a distinct extravascular presence of both IgG and Ca- 
A
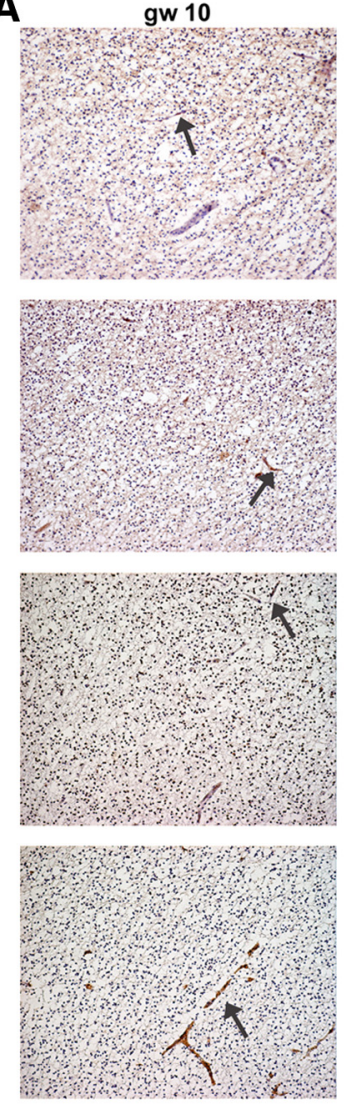

B

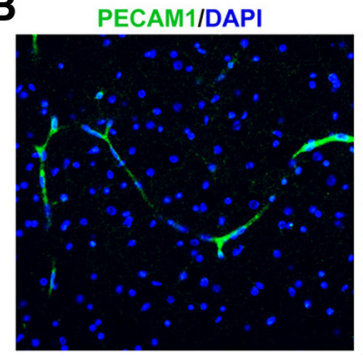

gw 16
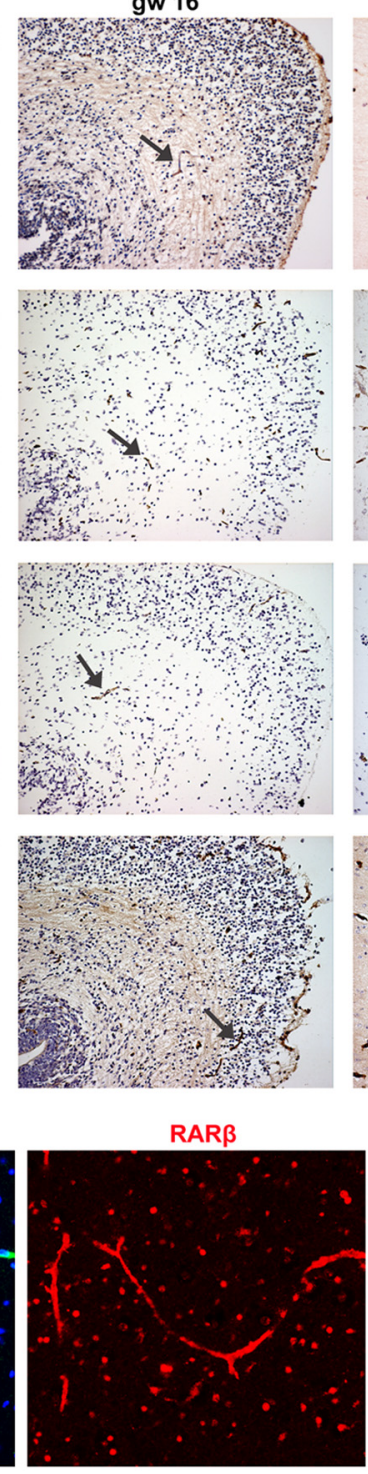
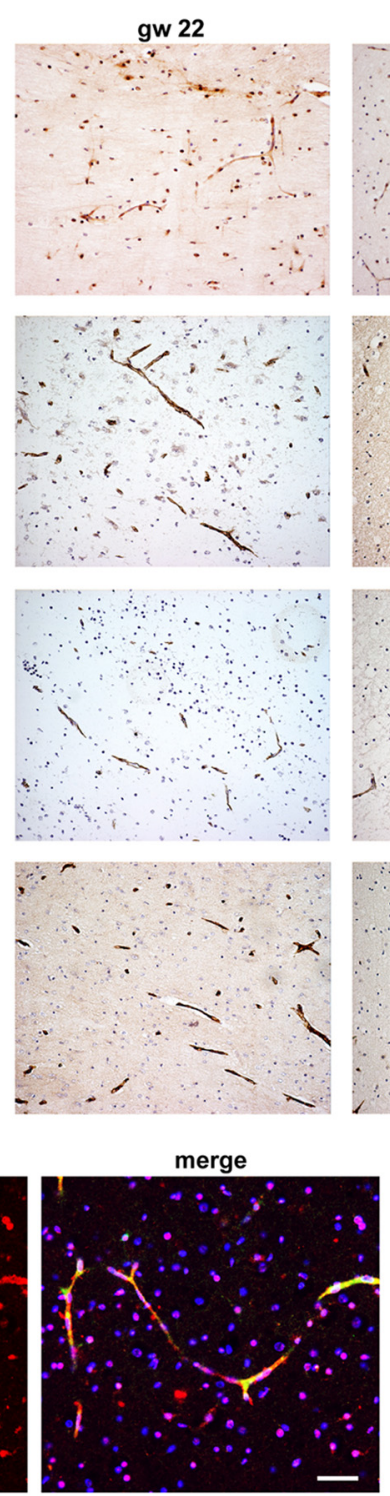

gw 29
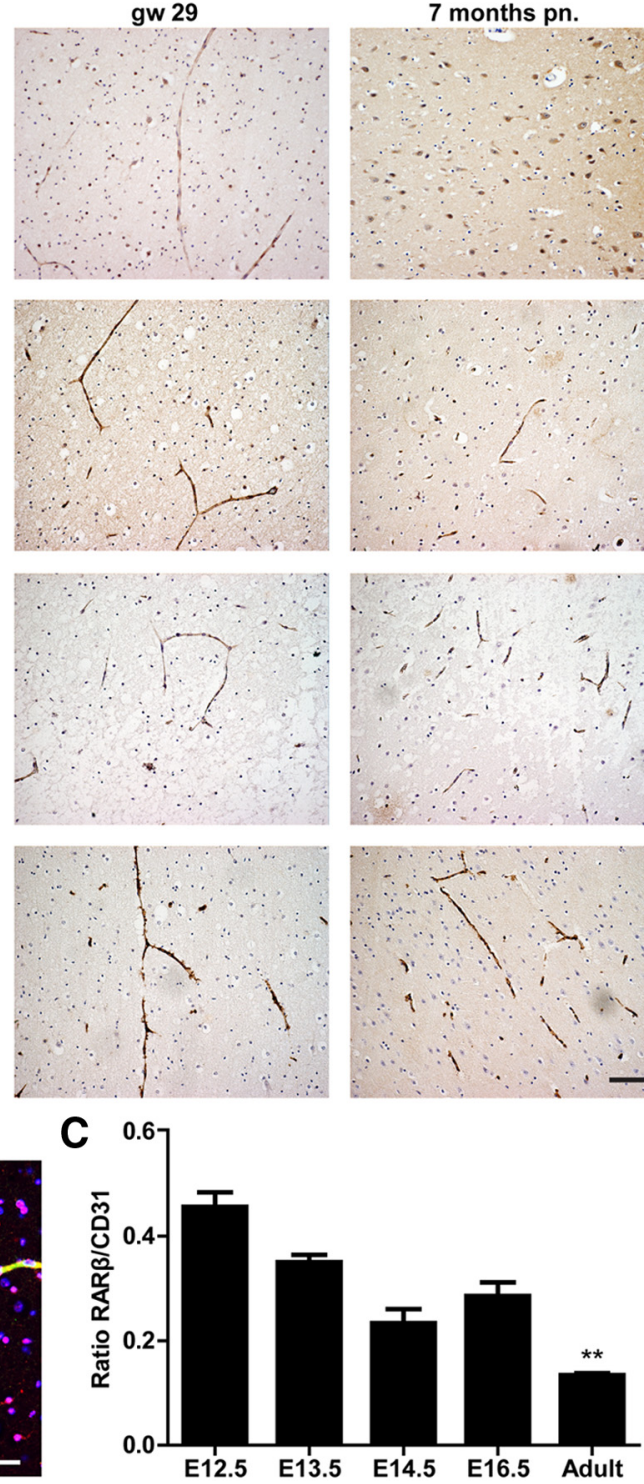

7 months pn.
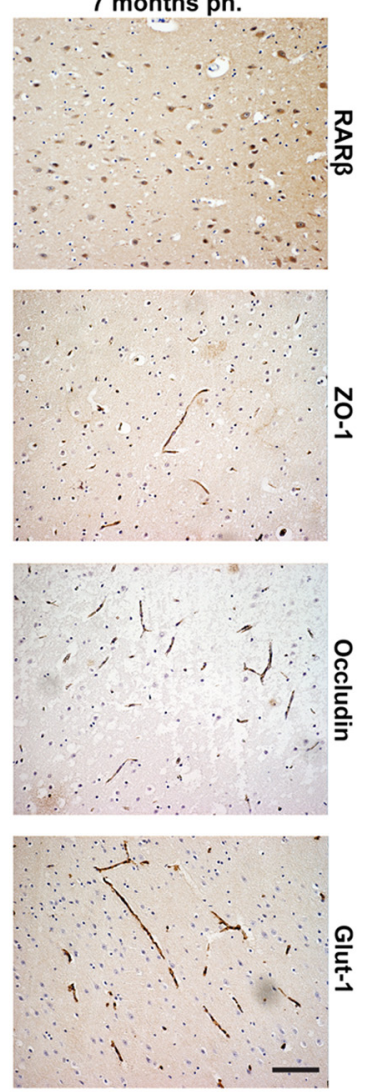

$\frac{Q}{5}$

Figure 4. RAR $\beta$ expression in the neurovasculature during cortical development. $\boldsymbol{A}$, Immunohistochemical analysis of RAR $\beta$, Z0-1, occludin, and Glut- 1 in paraffin sections of human cortical brain tissue at various stages of development. Note that from 10 weeks of gestation (gw), RAR $\beta$ is present in vascular structures (arrows). The vascular staining pattern becomes more pronounced in later stages of development (22 and 29 weeks of gestation) and is absent in postnatal brain [7 months postnatal (pn.)]. 20-1 and occludin immunoreactivity profiles follow that of RAR $\beta$ (arrows), whereas Glut-1 immunoreactivity in vascular structures precedes vascular RAR $\beta$ immunoreactivity. Scale bar, $50 \mu$ m. $\boldsymbol{B}$, Immunohistochemical analysis showing RAR $\beta$ (red) and PECAM1 (green) at 29 weeks of gestation; note that the PECAM1-positive structures overlap with RAR $\beta$, showing both nuclear and cytoplasmic RAR $\beta$ presence in fetal microvessels. Scale bar, $20 \mu$ m. $\boldsymbol{C}$, Gene expression levels of RAR $\beta$ in mouse whole-brain lysates during different developmental stages, corrected for PECAM1 gene expression levels $\left(1\right.$-way AN0VA). ${ }^{* *} p<0.01 ; n=4$.

daverine-Alexa Fluor-555 in cells surrounding the PECAM1positive vasculature. Double-labeling experiments with the neuronal nuclear antigen NeuN showed that both the IgG and Cadaverine-Alexa Fluor-555-positive cells are neurons (Fig. 5A). The average amount of IgG immunoreactivity and CadaverineAlexa Fluor-555 fluorescence per micrograph was found to be significantly higher in BMS493-treated embryonic brain sections compared with DMSO-treated embryos (IgG, $357.8 \pm 103.5 \%$ of control, $p=0.037$; Cadaverine-Alexa Fluor-555, $1650 \pm 554.5 \%$ of control; $p=0.025$, two-tailed Student's $t$ test). To analyze the BBB-related gene expression, the embryonic brains were isolated to study CNS gene expression levels only. BMS493-treated embryonic brains showed a significant decrease in gene expression levels of the major RA target gene RAR $\beta$ compared with vehicletreated controls $(-57.0 \pm 10.9 \%$ of control; Fig. $5 B)$. This confirms BMS493 efficacy to reduce RAR activation in the brain.
Importantly, BMS493 treatment did not affect the density of brain capillaries or PECAM1 gene expression levels, nor did it affect the expression of other brain cell-specific genes for astrocytes (GFAP), neurons (NeuN), and pericytes (PDGFRB) (data not shown). The expression levels of BBB-related genes $\mathrm{ZO}-1$ $(-32.2 \pm 8.6 \%$ of control), VE-cadherin $(-40.1 \pm 14.2 \%$ of control), and the $\mathrm{ABC}$ transporter gene breast cancer resistance protein (BCRP; $-34.9 \pm 14.2 \%$ of control) were significantly reduced in BMS493-treated embryos compared with vehicletreated embryos (Fig. 5B). Fluorescent immunohistochemical analysis of ZO-1 protein expression in BMS493-treated embryos revealed that ZO-1 is localized to PECAM1-positive structures but clearly showed a reduced immunoreactivity when compared with vehicle-treated embryo brain (Fig. 5C). BMS493 treatment did not significantly affect claudin-5 and occludin gene expression levels. Together, these data show that RA and RARs are 
A PECAM1/Cad-A555
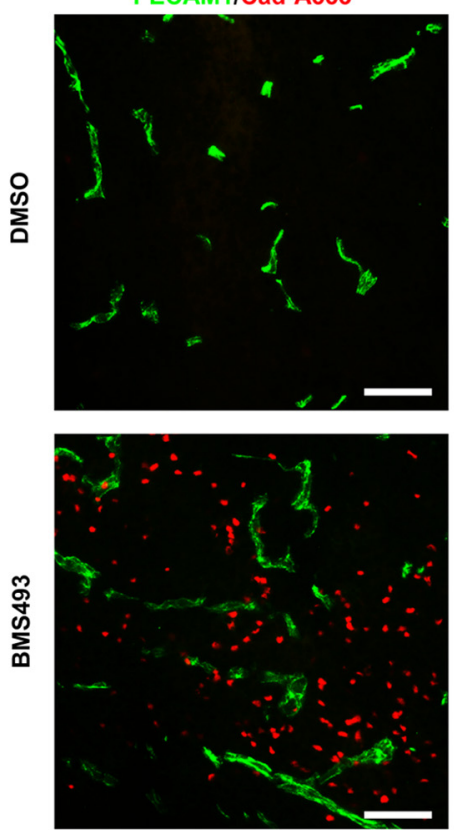

B

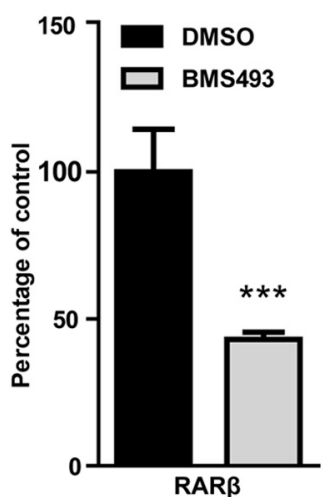

NeuN/Cad-A555
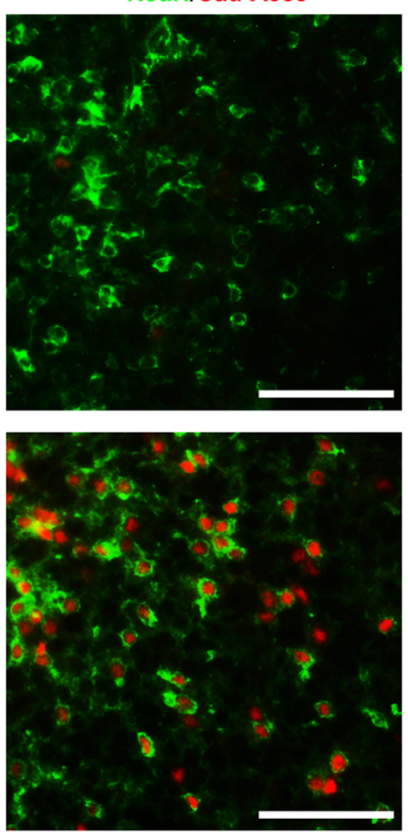

mIGG/PECAM-1
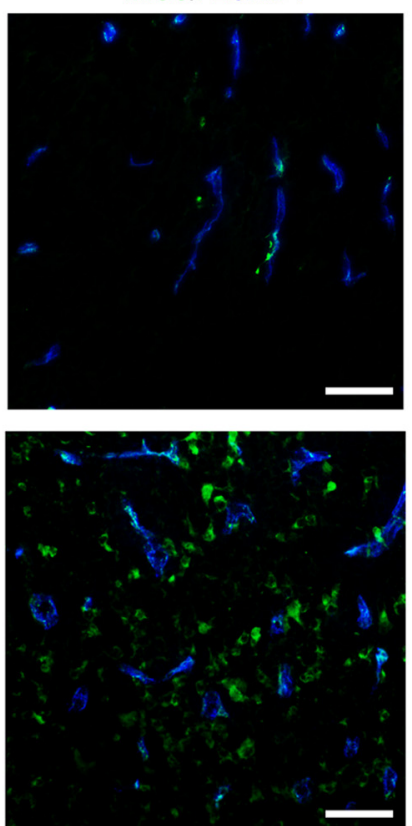

C

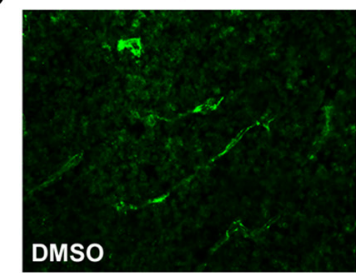

mIGG/NeuN
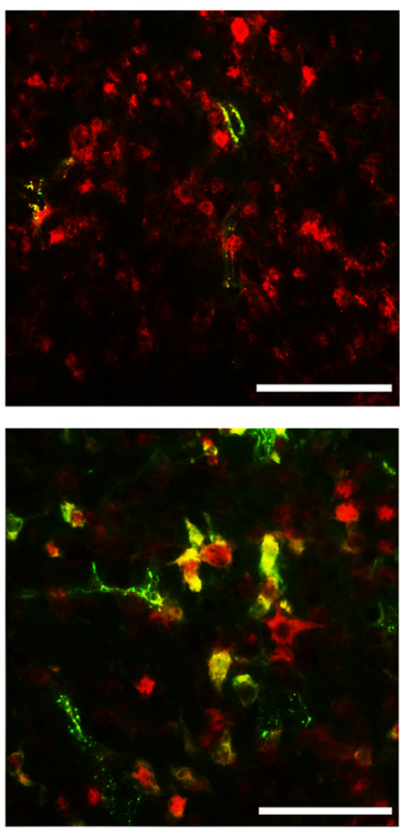

ZO-1/PECAM1
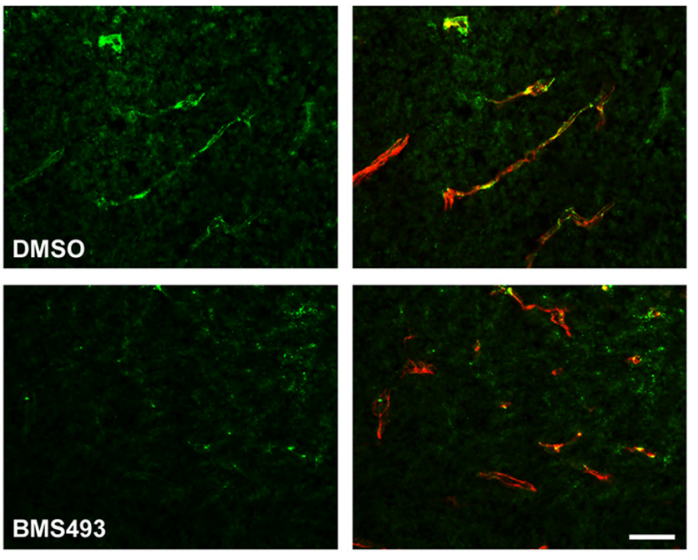

Figure 5. RAR antagonist BMS493 administration in pregnant mice results in increased permeability of the embryonic BBB, coinciding with decreased BBB gene expression. $A$, Immunohistochemical analysis showing endogenous lgG (mlGG, green) or Cadaverine-Alexa Fluor-555 (Cad-A555, red) with PECAM-1, and NeuN in embryonic brain of vehicle- and BMS493-treated embryos. Note that both the extravascular lgG-positive cells and Cadaverine-Alexa Fluor-555-positive cells have NeuN-positive nuclei/cytoplasm. Scale bars, $50 \mu \mathrm{m}$. $\boldsymbol{B}$, RAR $\beta$ gene expression level and gene expression levels of barrier-related genes are decreased in BMS493-treated embryonic brain compared with vehicle controls (2-tailed Student's $t$ test). $\boldsymbol{C}$, Immunohistochemical analysis showing Z0-1 (green) and PECAM1 (red). BMS493-treated embryonic brain shows a reduced immunoreactivity for Z0-1 with a junctional localization compared with vehicle-treated embryonic brain (arrowhead). Scale bar, $50 \mu \mathrm{m} .{ }^{*} p<0.05 ;{ }^{* *} p<0.01 ;{ }^{* * *} p<0.001 ; n=4$ for gene expression analysis.

implicated in the development of the murine $\mathrm{BBB}$ and that a reduction of RAR activity in the CNS leads to structural $\mathrm{BBB}$ impairment.

\section{Discussion}

To date, this is the first investigation of RA signaling focusing on the development of the BBB. The present study shows that RA signaling is involved in the induction of BBB development. During fetal brain development, RA is synthesized by RALDH1/2positive radial glial cells, and its corresponding receptor, $\operatorname{RAR} \beta$, is markedly expressed in developing human brain microvasculature. Moreover, in vitro analyses revealed that RA increases the formation of a tight barrier and mediates the expression of BBBrelated genes, including VE-cadherin, $\mathrm{P}$-gp, and $\mathrm{ZO}-1$, and conversely downregulated the permeability factor VEGF-A. Specific activation and knockdown studies identified $\operatorname{RAR} \beta$ as the major
RAR responsible for its barrier-enhancing effect in human brain ECs. Finally, treatment with an RAR antagonist caused a reduction in RAR activation during $\mathrm{BBB}$ development in mice and a decrease of BBB-related gene expression, functionally illustrated by the permeability to circulating IgG and exogenous tracer Cadaverine-Alexa Fluor-555.

RA is best known as a neuronal differentiation factor in the developing CNS. Interestingly, the developmental window in which the vasculature invades the CNS and matures into the BBB overlaps with the induction and patterning of neuronal differentiation and outgrowth (Tam and Watts, 2010), and both systems share certain guidance cues and differentiation-inducing signaling events during their development (Larrivée et al., 2009). Our findings point to RA as one of these common denominators of neuronal and vascular development. 
Specific differentiation of BBB ECs is crucial in safeguarding the CNS environment and normal neuronal function. We here report that the astrocyte precursors, radial glial cells, which are in close proximity to the developing CNS vasculature, are capable of RA production through the expression of RALDH. The current view on $\mathrm{BBB}$ development relies heavily on signals from the resident CNS cells, such as astrocytes, microglia (Abbott et al., 2010), and, more recently, pericytes (Armulik et al., 2010; Daneman et al., 2010). However, underlying mechanisms are just now beginning to emerge in the form of CNS-specific Wnt $/ \beta$-catenin signaling (Liebner et al., 2008; Stenman et al., 2008; Daneman et al., 2009), Sonic hedgehog (Shh) signaling (Alvarez et al., 2011), and intracellular stabilization signals mediated by VE-cadherin (Rudini et al., 2008; Taddei et al., 2008). We propose that RA signaling acts in concert with the signaling profile of CNS-specific Wnt and Shh pathways during maturation of the BBB. Besides directly acting on the ECs of the developing BBB, RA has been described to act as a regulator of Shh and Wnt pathways in the developing CNS (Halilagic et al., 2007), thereby linking the three pathways and possibly providing a time window of action for each separate pathway. Furthermore, a recent report describes a regulatory role for RA on the major developmental pathways of FGF and Notch signaling during spinal cord development (Paschaki et al., 2012), of which the Notch pathway has already been linked to BBB development and integrity (Li et al., 2011).

The dependence of neural progenitors on radial glial cellderived RA has been described previously (Környei et al., 2007; Kane et al., 2008; Wang et al., 2011). Moreover, the main receptor for RBP-bound retinol, STRA6, is expressed in the developing bovine CNS by a subset of large blood vessels and astrocytes surrounding the mainly STRA6-negative microvasculature (Kawaguchi et al., 2007). This implies that the ECs of the CNS microcirculation rely on RA synthesis by proximal radial glia. Another source of RA synthesis during CNS development was described in the form of neural progenitor cells (Engberg et al., 2010). This suggests that the role of RA synthesis might shift from one cell type to another as CNS development progresses. This is further strengthened by the finding that postnatal and adult rat astrocytes retain their capacity for RA synthesis, inducible by specific conditions (Shearer et al., 2012).

In vitro studies using a human brain endothelial barrier model revealed a potential working mechanism for RA at the developing BBB. Cultured fetal astrocytes induced an RA-dependent signal in brain ECs that lead to the modulation of different BBB aspects, including the formation of a tight barrier and the expression of $\mathrm{BBB}$-specific proteins. The maturation of angiogenic vasculature into a functional BBB requires the formation of high paracellular resistance. We show that RA leads to increased expression of VE-cadherin, occludin, and ZO-1, three molecules described to play a critical role in barrier integrity (Abbott et al., 2010). Moreover, the endothelial BBB phenotype encompasses the polarized expression of specific transport and efflux proteins, forming the metabolic barrier. RA highly increases the gene expression of P-gp and to a lesser extent the expression of Glut-1, showing that RA regulates various aspects of the brain endothelial barrier. Previous reports on RA-induced gene expression in brain ECs are in line with our findings, showing increased expression of P-gp (El Hafny et al., 1997) and the detoxifying enzyme $\gamma$-glutamyl transpeptidase (Lechardeur et al., 1995).

The induction of BBB aspects in cultured brain ECs by RA was dependent on the expression of RAR $\beta$, which shows high relative abundance compared with the two other RAR subtypes and was mimicked by specific RAR $\beta$ activation. Moreover, the antagonis- tic effect of BMS453 on RAR $\alpha$ and RAR $\gamma$ did not result in adverse effects on $\mathrm{Rb}$ value, showing that a functional barrier increase is not dependent on the activation of RAR $\alpha$ or RAR $\gamma$. The knockdown of RAR $\beta$ expression resulted in loss of endothelial barrier function and reduced expression of BBB markers. P-gp expression was unaffected by RAR $\beta$ knockdown, indicating that part of the metabolic barrier function might be regulated by $\operatorname{RAR} \alpha / \gamma /$ RXR heterodimers or other nuclear receptors. Furthermore, previous reports have shown RAR-mediated repression of gene transcription in the absence of RA as a ligand (for review, see Niederreither and Dollé, 2008), which may underlie the observed changes in endothelial gene expression. The importance of RAR $\beta$ at the BBB was further supported by expression analysis of the developing human brain. During fetal development of the CNS, $\operatorname{RAR} \beta$ is expressed in the ECs of the developing vasculature. This suggests their responsiveness to the local release of RA, and RAR $\beta$ expression is furthermore a clear indication of RA-dependent gene transcription (Liao et al., 2005). Vascular RAR $\beta$ expression seems to be conserved between mice and humans, because $\operatorname{RAR} \beta$ gene expression decreases during mouse brain development when corrected for vascular content.

To translate our findings to in vivo BBB development, we pharmacologically blocked the activation of RARs in utero. A major drawback in animal models in which RA production is fully ablated is that exogenous RA is needed to ensure successful conception and embryonic CNS development. Moreover, animals with an RAR-subtype deficiency often show redundancy effects, limiting the usefulness of the phenotypical observations (Ghyselinck et al., 1997), with additional complications arising from the loss of normal transcriptional repression by RARs in the absence of RA. Because BBB development starts from E10, with the ingrowth of ECs from the neural vascular plexus (Walls et al., 2008), this time point was chosen to start BMS493 treatment. Analysis of the accumulation of an injected tracer, Cadaverine, as well as of endogenous IgG in embryonic brains at E16.5 revealed a distinct extravascular staining pattern in BMS493-treated animals. This was not observed in control embryos, suggestive of serum leakage across a structurally impaired BBB. Intensely stained extravascular IgG deposits and Cadaverine-positive nuclei were found in NeuN-positive cells surrounding the CNS microvasculature, suggesting neuronal uptake of extravasated IgG and Cadaverine. For IgG, the finding is in line with a study describing BBB damage in a model for temporal lobe epilepsy (Rigau et al., 2007), in which IgG-positive neurons were observed in the hippocampus after BBB damage, coinciding with a decrease of vascular ZO-1 expression. Comparable findings were described in an animal model for amyotrophic lateral sclerosis (ALS) (Alexianu et al., 2001), as well as in ALS patients (Engelhardt and Appel, 1990). The accumulation of Cadaverine-Alexa Fluor-555 in neurons has been described in mice after BBB dysfunction as a result of a lack of pericytes (Armulik et al., 2010) and apolipoprotein E4 deficiency (Bell et al., 2012). Accompanying the observed permeability to serum proteins, we found decreased expression levels of ZO-1, VE-cadherin, and BCRP, whereas the total number of PECAM1-positive vascular structures was unaltered. Furthermore, ZO-1 immunoreactivity on the microvasculature as well as a clear junctional localization was reduced in BMS493-treated embryonic brains. Considering the regulatory role for RA in BBB-associated pathways like Shh- and Wntsignaling, indirect effects of RAR-inhibition via these pathways might be considered. However, our in vitro studies describe a direct effect of RA on brain ECs and RAR $\beta$ expression is located at the developing BBB in the human fetal CNS. Together, these 
findings suggest a direct role for RA on endothelial maturation in the developing BBB.

The search for developmental cues involved in BBB formation has implications for neurodegenerative disorders in which $\mathrm{BBB}$ disruption is paramount. Many reports show the association of BBB breakdown with pathology of CNS disorders, such as multiple sclerosis (van Horssen et al., 2007; Kooij et al., 2010, 2011; Neuwelt et al., 2011), in which restoring BBB function may provide new ways to counteract these disorders. Developmental pathways activated by RA that induce BBB function could prove to be important targets to boost the self-regenerative capacity of the adult brain.

\section{References}

Abbott NJ, Rönnbäck L, Hansson E (2006) Astrocyte-endothelial interactions at the blood-brain barrier. Nat Rev Neurosci 7:41-53. CrossRef Medline

Abbott NJ, Patabendige AA, Dolman DE, Yusof SR, Begley DJ (2010) Structure and function of the blood-brain barrier. Neurobiol Dis 37:13-25. CrossRef Medline

Aird WC (2007a) Phenotypic heterogeneity of the endothelium. I. Structure, function, and mechanisms. Circ Res 100:158-173. CrossRef Medline

Aird WC (2007b) Phenotypic heterogeneity of the endothelium. II. Representative vascular beds. Circ Res 100:174-190. CrossRef Medline

Alexianu ME, Kozovska M, Appel SH (2001) Immune reactivity in a mouse model of familial ALS correlates with disease progression. Neurology 57: 1282-1289. CrossRef Medline

Alvarez JI, Dodelet-Devillers A, Kebir H, Ifergan I, Fabre PJ, Terouz S, Sabbagh M, Wosik K, Bourbonnière L, Bernard M, van Horssen J, de Vries HE, Charron F, Prat A (2011) The Hedgehog pathway promotes bloodbrain barrier integrity and CNS immune quiescence. Science 334:17271731. CrossRef Medline

Armulik A, Genov é G, Mäe M, Nisancioglu MH, Wallgard E, Niaudet C, $\mathrm{He}$ L, Norlin J, Lindblom P, Strittmatter K, Johansson BR, Betsholtz C (2010) Pericytes regulate the blood-brain barrier. Nature 468:557-561. CrossRef Medline

Bell RD, Winkler EA, Singh I, Sagare AP, Deane R, Wu Z, Holtzman DM, Betsholtz C, Armulik A, Sallstrom J, Berk BC, Zlokovic BV (2012) Apolipoprotein E controls cerebrovascular integrity via cyclophilin A. Nature 485:512-516. CrossRef Medline

Chanas-Sacre G, Rogister B, Moonen G, Leprince P (2000) Radial glia phenotype: origin, regulation, and transdifferentiation. J Neurosci Res 61: 357-363. CrossRef Medline

Daneman R, Agalliu D, Zhou L, Kuhnert F, Kuo CJ, Barres BA (2009) Wnt/ beta-catenin signaling is required for CNS, but not non-CNS, angiogenesis. Proc Natl Acad Sci U S A 106:641-646. CrossRef Medline

Daneman R, Zhou L, Kebede AA, Barres BA (2010) Pericytes are required for blood-brain barrier integrity during embryogenesis. Nature 468:562566. CrossRef Medline

Duester G (2008) Retinoic acid synthesis and signaling during early organogenesis. Cell 134:921-931. CrossRef Medline

El Hafny B, Chappey O, Piciotti M, Debray M, Boval B, Roux F (1997) Modulation of P-glycoprotein activity by glial factors and retinoic acid in an immortalized rat brain microvessel endothelial cell line. Neurosci Lett 236:107-111. CrossRef Medline

Engberg N, Kahn M, Petersen DR, Hansson M, Serup P (2010) Retinoic acid synthesis promotes development of neural progenitors from mouse embryonic stem cells by suppressing endogenous, Wnt-dependent nodal signaling. Stem Cells 28:1498-1509. CrossRef Medline

Engelhardt JI, Appel SH (1990) IgG reactivity in the spinal cord and motor cortex in amyotrophic lateral sclerosis. Arch Neurol 47:1210-1216. CrossRef Medline

Fontijn RD, Volger OL, Fledderus JO, Reijerkerk A, de Vries HE, Horrevoets AJ (2008) SOX-18 controls endothelial-specific claudin-5 gene expression and barrier function. Am J Physiol Heart Circ Physiol 294:H891H900. CrossRef Medline

García-Vallejo JJ, Van Het Hof B, Robben J, Van Wijk JA, Van Die I, Joziasse DH, Van Dijk W (2004) Approach for defining endogenous reference genes in gene expression experiments. Anal Biochem 329:293-299. CrossRef Medline
Germain P, Kammerer S, Pérez E, Peluso-Iltis C, Tortolani D, Zusi FC, Starrett J, Lapointe P, Daris JP, Marinier A, de Lera AR, Rochel N, Gronemeyer H (2004) Rational design of RAR-selective ligands revealed by RARbeta crystal stucture. EMBO Rep 5:877-882. CrossRef Medline

Ghyselinck NB, Dup é V, Dierich A, Messaddeq N, Garnier JM, Rochette-Egly C, Chambon P, Mark M (1997) Role of the retinoic acid receptor beta (RARbeta) during mouse development. Int J Dev Biol 41:425-447. Medline

Giaever I, Keese CR (1991) Micromotion of mammalian cells measured electrically. Proc Natl Acad Sci U S A 88:7896-7900. CrossRef Medline

Greenberg DA, Jin K (2005) From angiogenesis to neuropathology. Nature 438:954-959. CrossRef Medline

Halilagic A, Ribes V, Ghyselinck NB, Zile MH, Doll é P, Studer M (2007) Retinoids control anterior and dorsal properties in the developing forebrain. Dev Biol 303:362-375. CrossRef Medline

Jain RK (2003) Molecular regulation of vessel maturation. Nat Med 9:685693. CrossRef Medline

Kagechika H (2002) Novel synthetic retinoids and separation of the pleiotropic retinoidal activities. Curr Med Chem 9:591-608. CrossRef Medline

Kane MA, Folias AE, Wang C, Napoli JL (2008) Quantitative profiling of endogenous retinoic acid in vivo and in vitro by tandem mass spectrometry. Anal Chem 80:1702-1708. CrossRef Medline

Kawaguchi R, Yu J, Honda J, Hu J, Whitelegge J, Ping P, Wiita P, Bok D, Sun $\mathrm{H}$ (2007) A membrane receptor for retinol binding protein mediates cellular uptake of vitamin A. Science 315:820-825. CrossRef Medline

Kooij G, van Horssen J, de Lange EC, Reijerkerk A, van der Pol SM, van Het Hof B, Drexhage J, Vennegoor A, Killestein J, Scheffer G, Oerlemans R, Scheper R, van der Valk P, Dijkstra CD, de Vries HE (2010) T lymphocytes impair P-glycoprotein function during neuroinflammation. J Autoimmun 34:416-425. CrossRef Medline

Kooij G, Mizee MR, van Horssen J, Reijerkerk A, Witte ME, Drexhage JA, van der Pol SM, van Het Hof B, Scheffer G, Scheper R, Dijkstra CD, van der Valk P, de Vries HE (2011) Adenosine triphosphate-binding cassette transporters mediate chemokine (C-C motif) ligand 2 secretion from reactive astrocytes: relevance to multiple sclerosis pathogenesis. Brain 134:555-570. CrossRef Medline

Környei Z, Gócza E, Rühl R, Orsolits B, Vörös E, Szab ó B, Vágovits B, Madarász E (2007) Astroglia-derived retinoic acid is a key factor in gliainduced neurogenesis. FASEB J 21:2496-2509. CrossRef Medline

Larrivée B, Freitas C, Suchting S, Brunet I, Eichmann A (2009) Guidance of vascular development: lessons from the nervous system. Circ Res 104: 428-441. CrossRef Medline

Lechardeur D, Schwartz B, Paulin D, Scherman D (1995) Induction of blood-brain barrier differentiation in a rat brain-derived endothelial cell line. Exp Cell Res 220:161-170. CrossRef Medline

Li F, Lan Y, Wang Y, Wang J, Yang G, Meng F, Han H, Meng A, Wang Y, Yang X (2011) Endothelial Smad4 maintains cerebrovascular integrity by activating N-cadherin through cooperation with Notch. Dev Cell 20:291302. CrossRef Medline

Liao WL, Wang HF, Tsai HC, Chambon P, Wagner M, Kakizuka A, Liu FC (2005) Retinoid signaling competence and RARbeta-mediated gene regulation in the developing mammalian telencephalon. Dev Dyn 232:887900. CrossRef Medline

Liebner S, Corada M, Bangsow T, Babbage J, Taddei A, Czupalla CJ, Reis M, Felici A, Wolburg H, Fruttiger M, Taketo MM, von Melchner H, Plate $\mathrm{KH}$, Gerhardt H, Dejana E (2008) Wnt/beta-catenin signaling controls development of the blood-brain barrier. J Cell Biol 183:409-417. CrossRef Medline

Mathiisen TM, Lehre KP, Danbolt NC, Ottersen OP (2010) The perivascular astroglial sheath provides a complete covering of the brain microvessels: an electron microscopic 3D reconstruction. Glia 58:1094-1103. CrossRef Medline

Matt N, Ghyselinck NB, Wendling O, Chambon P, Mark M (2003) Retinoic acid-induced developmental defects are mediated by RARbeta/RXR heterodimers in the pharyngeal endoderm. Development 130:2083-2093. CrossRef Medline

Mey J (2006) New therapeutic target for CNS injury? The role of retinoic acid signaling after nerve lesions. J Neurobiol 66:757-779. CrossRef Medline

Neuwelt EA, Bauer B, Fahlke C, Fricker G, Iadecola C, Janigro D, Leybaert L, Molnár Z, O'Donnell ME, Povlishock JT, Saunders NR, Sharp F, Stanimirovic D, Watts RJ, Drewes LR (2011) Engaging neuroscience to ad- 
vance translational research in brain barrier biology. Nat Rev Neurosci 12:169-182. CrossRef Medline

Niederreither K, Doll é P (2008) Retinoic acid in development: towards an integrated view. Nat Rev Genet 9:541-553. CrossRef Medline

Pachter JS, de Vries HE, Fabry Z (2003) The blood-brain barrier and its role in immune privilege in the central nervous system. J Neuropathol Exp Neurol 62:593-604. Medline

Paschaki M, Lin SC, Wong RL, Finnell RH, Doll é P, Niederreither K (2012) Retinoic acid-dependent signaling pathways and lineage events in the developing mouse spinal cord. PLoS One 7:e32447. CrossRef Medline

Quadro L, Hamberger L, Gottesman ME, Wang F, Colantuoni V, Blaner WS, Mendelsohn CL (2005) Pathways of vitamin A delivery to the embryo: insights from a new tunable model of embryonic vitamin A deficiency. Endocrinology 146:4479-4490. CrossRef Medline

Rigau V, Morin M, Rousset MC, de Bock F, Lebrun A, Coubes P, Picot MC, Baldy-Moulinier M, Bockaert J, Crespel A, Lerner-Natoli M (2007) Angiogenesis is associated with blood-brain barrier permeability in temporal lobe epilepsy. Brain 130:1942-1956. CrossRef Medline

Risau W, Wolburg H (1990) Development of the blood-brain barrier. Trends Neurosci 13:174-178. CrossRef Medline

Rudini N, Felici A, Giampietro C, Lampugnani M, Corada M, Swirsding K, Garr è M, Liebner S, Letarte M, ten Dijke P, Dejana E (2008) VEcadherin is a critical endothelial regulator of TGF-beta signalling. EMBO J 27:993-1004. CrossRef Medline

Santaguida S, Janigro D, Hossain M, Oby E, Rapp E, Cucullo L (2006) Side by side comparison between dynamic versus static models of blood-brain barrier in vitro: a permeability study. Brain Res 1109:1-13. CrossRef Medline

Shearer KD, Fragoso YD, Clagett-Dame M, McCaffery PJ (2012) Astrocytes as a regulated source of retinoic acid for the brain. Glia 60:1964-1976. CrossRef Medline

Stenman JM, Rajagopal J, Carroll TJ, Ishibashi M, McMahon J, McMahon AP (2008) Canonical Wnt signaling regulates organ-specific assembly and differentiation of CNS vasculature. Science 322:1247-1250. CrossRef Medline

Stewart PA, Wiley MJ (1981) Developing nervous tissue induces formation of blood-brain barrier characteristics in invading endothelial cells: a study using quail-chick transplantation chimeras. Dev Biol 84:183-192. CrossRef Medline

Taddei A, Giampietro C, Conti A, Orsenigo F, Breviario F, Pirazzoli V, Potente M, Daly C, Dimmeler S, Dejana E (2008) Endothelial adherens junctions control tight junctions by VE-cadherin-mediated upregulation of claudin-5. Nat Cell Biol 10:923-934. CrossRef Medline

Tam SJ, Watts RJ (2010) Connecting vascular and nervous system development: angiogenesis and the blood-brain barrier. Annu Rev Neurosci 33: 379-408. CrossRef Medline

van de Pavert SA, Olivier BJ, Goverse G, Vondenhoff MF, Greuter M, Beke P, Kusser K, Höpken UE, Lipp M, Niederreither K, Blomhoff R, Sitnik K, Agace WW, Randall TD, de Jonge WJ, Mebius RE (2009) Chemokine CXCL13 is essential for lymph node initiation and is induced by retinoic acid and neuronal stimulation. Nat Immunol 10:1193-1199. CrossRef Medline

van Horssen J, Brink BP, de Vries HE, van der Valk P, B ø L (2007) The blood-brain barrier in cortical multiple sclerosis lesions. J Neuropathol Exp Neurol 66:321-328. CrossRef Medline

Walls JR, Coultas L, Rossant J, Henkelman RM (2008) Three-dimensional analysis of vascular development in the mouse embryo. PLoS One 3:e2853. CrossRef Medline

Wang C, Kane MA, Napoli JL (2011) Multiple retinol and retinal dehydrogenases catalyze all-trans-retinoic acid biosynthesis in astrocytes. J Biol Chem 286:6542-6553. CrossRef Medline

Weksler BB, Subileau EA, Perrière N, Charneau P, Holloway K, Leveque M, Tricoire-Leignel H, Nicotra A, Bourdoulous S, Turowski P, Male DK, Roux F, Greenwood J, Romero IA, Couraud PO (2005) Blood-brain barrier-specific properties of a human adult brain endothelial cell line. FASEB J 19:1872-1874. CrossRef Medline

Wendling O, Dennefeld C, Chambon P, Mark M (2000) Retinoid signaling is essential for patterning the endoderm of the third and fourth pharyngeal arches. Development 127:1553-1562. Medline

Weston AD, Chandraratna RA, Torchia J, Underhill TM (2002) Requirement for RAR-mediated gene repression in skeletal progenitor differentiation. J Cell Biol 158:39-51.

Wong LF, Yip PK, Battaglia A, Grist J, Corcoran J, Maden M, Azzouz M, Kingsman SM, Kingsman AJ, Mazarakis ND, McMahon SB (2006) Retinoic acid receptor beta2 promotes functional regeneration of sensory axons in the spinal cord. Nat Neurosci 9:243-250. CrossRef Medline

Wosik K, Cayrol R, Dodelet-Devillers A, Berthelet F, Bernard M, Moumdjian R, Bouthillier A, Reudelhuber TL, Prat A (2007) Angiotensin II controls occludin function and is required for blood brain barrier maintenance: relevance to multiple sclerosis. J Neurosci 27:9032-9042. CrossRef Medline 